\title{
Breeding, early development and larval rearing of cloudy damsel, Dascyllus carneus Fischer, 1885
}

\author{
F. Muhammed Anzeer ${ }^{\mathrm{a}}$, K.S. Aneesh ${ }^{\mathrm{a}}$, Mijo V. Abraham ${ }^{\mathrm{a}}$, S. Darsana ${ }^{\mathrm{a}}$, B. Santhosh ${ }^{\mathrm{a}, *}$, M.K. Anil ${ }^{\mathrm{a}}$, \\ A. Gopalakrishnan ${ }^{b}$, A. Udayakumar ${ }^{a}$, H. Jose Kingsly ${ }^{a}$, C. Unnikrishnan ${ }^{a}$, Greever Yoyak ${ }^{a}$ \\ ${ }^{a}$ Vizhinjam Research Centre of ICAR-Central Marine Fisheries Research Institute, Vizhinjam, Thiruvananthapuram 695 521, Kerala, India \\ ${ }^{\mathrm{b}}$ ICAR-Central Marine Fisheries Research Institute, Kochi 682 018, Kerala, India
}

\section{A R T I C L E I N F O}

\section{Keywords:}

Marine ornamental fishes

Pomacentridae

Larval rearing

Parvocalanus crassirostris

Copepods

Mouth gape

\begin{abstract}
A B S T R A C T
As the demand for marine ornamental fish is ever increasing, the industry largely relies on collections from natural habitat due to insufficient breeding and seed production technologies. Fishes of the family Pomacentridae are popular in marine aquaria throughout the world. Among these, damsel fishes of the genus Dascyllus has high demand and are mostly collected from the wild. The present study forms the first-ever report on successful breeding and larval development of Cloudy Damsel (Dascyllus carneus Fischer, 1885). Though there are a few reports on breeding of other species of Dascyllus, there has been no report on the complete larval development of any of the species in this genus. This forms the first description of early larval development of a Dascyllus species. Using the copepod Parvocalanus crassirostris as first feed the larval rearing was done. Successful breeding and larval development were achieved from the wild-caught broodstock of D. carneus at Vizhinjam Research Centre of ICAR-CMFRI, India. Brood stock from the wild took 4 months to spawn, laid 6500-10,500 eggs per spawning and hatching rate ranged from 90.6 to $98.81 \%$. Newly hatched larvae were the smallest among all the reported larvae of pomacentrid fishes and measured $1.95 \pm 0.14 \mathrm{~mm}$ in total length. Yolk reserve was completely absorbed within $72 \mathrm{~h}$ of hatching. Preflexion stage is from 4 to $10 \mathrm{dph}$, flexion stage is from 11 to $12 \mathrm{dph}$ and postflexion period is 13-15 dph. Larvae accepted only copepod naupliar stages as first feed and calanoid copepod $P$. crassirostris alone was fed until $25 \mathrm{dph}$. Larvae settled from planktonic stage in 22-23 days and all the larvae metamorphosed into juveniles by $50 \mathrm{dph}$. The egg development, larval development and larval pigmentation up to $50 \mathrm{dph}$ has been described. The feeding protocols and feed size preference in relation to their age or mouth gape, the gut contents and mouth gape of the larvae caught from a feed trial with surplus copepods of all stages were analysed at regular intervals. Larvae preferred larger stages of copepods in later stages of their development. Finally larval feeding protocols were modified accordingly and better survival was observed. A final feeding regime has been developed and a strategy for the consistent hatchery production of this species was achieved. Different stages of copepod $P$. crassirostris were used till the settlement of planktonic stage of larvae and Artemia nauplii were used from $25 \mathrm{dph}$. The larvae were completely weaned to artificial diet from $50 \mathrm{dph}$.
\end{abstract}

\section{Introduction}

In recent years, marine ornamental fishes are gaining popularity in global aquarium fish trade and at present $>2000$ species of coral reef fishes are there in this trade (Biondo, 2017). Among these, hatchery production has been standardised for only few species of fishes. The freshwater ornamental fish trade almost completely depends on captive bred species. $>90 \%$ of economically important marine ornamental fishes are from the wild, exclusively from coral reef ecosystems all around the world (Sweet, 2016; Fotedar and Phillips, 2011).
Members of the family Pomacentridae are popular in marine aquariums throughout the world. In India, within the family Pomacentridae, five species (Amphiprion sebae, A. clarkii, Pomacentrus caeruleus, Dascyllus trimaculatus and Neopomacentrus nemurus) together contributes more than half the volume $(57.9 \%)$ of total marine ornamental trade (Prakash et al., 2017).

Till date, 90 species of marine ornamental fishes, 30 of these pomacentrids, have been bred in captivity but the attempts for mass scale production of many species have not yet been standardised. Among those, the early stages in the life of only $15 \%$ of pomacentrid species

\footnotetext{
* Corresponding author.

E-mail address: santhoshars@gmail.com (B. Santhosh).
} 
have been described to any level and the quality and extent of existing descriptions are also not uniform (Danilowicz and Brown, 1992; Murphy et al., 2007; Moorhead and Zeng, 2010; Setu et al., 2010; Madhu and Rema, 2014).

Family Pomacentridae consists of 413 species in 29 genera (Fricke et al., 2018). Damselfishes are common in shallow coral reef areas of tropical and subtropical seas (Allen, 1991). Currently there are 396 recognised species of damselfishes (Cooper and Santini, 2016; Fricke et al., 2018). As of now the genus Dascyllus includes 11 species (Getlekha et al., 2016; Fricke et al., 2018) and these are primarily the inhabitants of tropical reefs. Dascyllus carneus Fischer, 1885, popularly known as cloudy damsel was selected for broodstock development and breeding trials here. Distribution of the species is limited to the Indian Ocean (Randall and Allen, 1977). This species is being exploited from the wild due to its attractive colour pattern. This is an important species among the marine ornamentals fishes which has a very good demand both in domestic and international markets (Froese and Pauly, 2018) as it is comparatively hardy, attractive and grow well in community tanks. The eggs and larvae of Dascyllus spp. are the smallest among pomacentrid fishes (Tanaka, 1999).

Sixteen species of pomacentrids have been successfully bred in captivity by the ICAR-Central Marine Fisheries Research Institute. These are orange clown (Amphiprion percula), false clown (A. ocellaris), sebae clown (A. sebae), Maldive's clownfish (A. nigripes), red saddleback clownfish (A. ephippium), pink skunk (A. perideraion), Clark's anemonefish (A. clarkii), maroon clown (Premnas biaculeatus), blue damsel (Pomacentrus caeruleus), peacock damsel (P. pavo), three spot damsel (Dascyllus trimaculatus), humbug damsel (D. aruanus), bluegreen damsel (Chromis viridis), yellowtail damsel (Neopomacentrus nemurus), filamentous tail damsel ( $N$. cyanomos), and sapphire devil damsel (Chrysiptera cyanea) (Madhu et al., 2013).

Damselfishes being brilliantly coloured are a highly sought after fish for marine aquarium keeping. Habitat destruction and indiscriminate exploitation of these fishes from wild reduced their natural population in many areas (Sin et al., 1994; Prakash et al., 2017). Sin et al. (1994) emphasized the need for studies on ecology and biology of these fishes and recommended strong action for conservation of the existing stock in the wild. Prakash et al. (2017) pointed out the importance of seed production and breeding of these fishes for reducing the wild collection. $D$. carneus is often reported to be endangered in several localities (Fricke et al., 2009; Chong et al., 2010; Arai, 2015).

Despite the few attempts to breed $D$. carneus by Sreeraj (2002) and Gopakumar et al. (2009b), there has been no information available on the breeding of this species. This is one of the most difficult damsel species for seed production due to its small sized larvae (Gopakumar, pers. comm.) and so far there is no report on larval rearing of this species. The present study is the first-ever report on broodstock development, breeding and successful larval rearing of Dascyllus carneus Fischer, 1885. This species has been successfully bred for two generations in hatchery and seed production technology has also been developed.

\section{Materials and methods}

\subsection{Broodstock collection, transportation and acclimatization}

Broodstocks of Dascyllus carneus were collected from the Tuticorin waters of Tamil Nadu, East Coast of India and were transported to Vizhinjam Research Centre of CMFRI, Thiruvananthapuram, Kerala, India in polyethylene bags with oxygen. Seven fishes collected were in the size range of $4.5-7.3 \mathrm{~cm}$. After the temperature acclimatization, the fishes were stocked in $500 \mathrm{~L}$ HDPE tanks with $250 \mathrm{~L}$ of sea water with biological filters. The fishes were fed with a mixture of boiled and fresh mussel meat 3 times a day with $10 \%$ water exchange daily. The broodstocks maintained under natural photoperiod (12 D: $12 \mathrm{~L}$ ) inside the hatchery. Water temperature ranged between 27.2 and $29.5^{\circ} \mathrm{C}$, pH 8-8.2 and salinity between 33 and 35 ppt.

\subsection{Breeding pair formation and breeding behaviour}

Any change in the behaviour of fish were observed and recorded. The responses and interactions of the other individuals were also recorded separately. The breeding behaviour was photographed using a digital camera (Nikon D7100).

\subsection{Spawning}

The brood stock tanks were provided with small pots made of clay from the initial period of broodstock development. Pots were brown in colour with a hole $(10-15 \mathrm{~cm})$ at the bottom. Pots were kept upside down which formed a perfect shelter for the broodstock to settle down. Within few days, the fishes started considering the pot as their territory and also as a substratum for depositing the eggs.

\subsection{Nature of the eggs and its development}

To study the developmental stages and for taking measurements, eggs were collected carefully from the surface of the pot using scrapers and taken in a small petri dish with fresh sea water. Developmental stages of the eggs were observed and measurements were taken using Leica S8APO stereo zoom microscope with Leica DFC 290 camera and Leica application suite version 4.1.0 software. Developmental stages of eggs were recorded at an interval of $1 \mathrm{~h}$ for the first day, $2 \mathrm{~h}$ for the second day and for $3 \mathrm{~h}$ for the third day.

\subsection{Hatching and larval rearing}

After incubation for $55 \mathrm{~h}$ inside the breeding tank, pots with the eggs were carefully transferred to the pre-prepared larval rearing tanks. While transferring clay pots from broodstock tanks to larval rearing tanks, egg patches on the pots were photographed using a digital camera (Nikon D7100) and the number of eggs were counted from the photographs. After hatching, the pot was removed, unhatched and opaque eggs were counted and the hatching percentage was calculated. The larval hatching and rearing were carried out in rectangular, dark brown coloured tanks of size $1 \times 1.95 \times 0.5 \mathrm{~m}$. (975 L capacity) with $500 \mathrm{~L}$ of green water. Gentle regulated aeration was given around the pot using small aeration stones to mimic the fanning by parents. No water exchange was done up to 10 days and after that, everyday $10 \%$ of water was removed using narrow tubes from the bottom and $12 \%$ of fresh seawater was added back with minimal disturbance till $25 \mathrm{dph}$ and later 15\% water was exchanged daily. Physico-chemical parameters such as atmospheric temperature, water temperature, salinity, dissolved oxygen, total ammoniacal nitrogen (TAN), $\mathrm{NH}_{3}-\mathrm{N}, \mathrm{NH}_{4}-\mathrm{N}$ and $\mathrm{pH}$ were monitored regularly (APHA, 1998).

\subsection{Live feed culture}

From the stock culture of algae maintained at ICAR- CMFRI, mass culture of Isochrysis galbana, Chlorella marina, Nannochloropsis oculata and $N$. salina were produced in circular tanks of $1 \mathrm{t}$ capacity. Algal cultures were prepared using recommended doses of fertilizers in FRP tanks. Algae cultured were harvested regularly and used for making green water for larval rearing and also for live feeds like copepods and rotifers. Artemia nauplii were also allowed to feed algae for a short period before using this as a feed for fish larvae.

Mass culture of rotifer (Brachionus plicatilis) was maintained at high density and fed with a mixture of algae I. galbana, N. oculata, N. salina and C. marina in circular tanks of $1 \mathrm{t}$ capacity. Artemia cysts were also kept ready for use. Among the stock culture of copepods maintained at Vizhinjam Research Centre of ICAR-CMFRI (Santhosh et al., 2018) the mass cultures of calanoid copepod Parvocalanus crassirostris were initiated in $1 \mathrm{t}$ FRP tanks, 5 days before the larval rearing (Anzeer et al., 2018). The copepods were fed with an equal mixture of microalgae $I$. 
galbana, C. marina and N. salina.

\subsection{Feeding trials}

\subsubsection{Trials for identification of feed preference}

All larval rearing trials were conducted using green water technique. $N$. oculata and $I$. galbana were used in the ratio of $1: 1$ for the preparation of green water. The final algal density in all the larval rearing tanks was maintained at $1 \times 10^{5}$ cells $\mathrm{mL}^{-1}$. The experiment was carried out in three sets of 500 L HDPE tanks in three replicates containing $300 \mathrm{~L}$ of green water. For each tank, 300 newly hatched larvae were stocked. The experiment continued for 15 days and the survival has been noted at 5 days intervals on each trial. Live feeds were introduced on $2 \mathrm{dph}$ in all the tanks. In this experiment, one set of tanks were inoculated with rotifer $B$. plicatilis at the rate of 10 ind. $\mathrm{mL}^{-1}$ alone as live feed. In second set of tanks, calanoid copepod P. crassirostris nauplii were introduced from mass culture tanks at the rate of 10 ind. $\mathrm{mL}^{-1}$. In third set of tanks, larvae were fed with a combination of B. plicatilis (5 ind. $\mathrm{mL}^{-1}$ ) and nauplii of $P$. crassirostris $\left(5\right.$ ind. $\mathrm{mL}^{-1}$ ). Water quality parameters were maintained at optimum levels in all tanks throughout the study. The results were statistically analysed using SPPS Statistics 20.

\subsubsection{Assessment of mouth gape and size of larval feed}

Since survival was noted only in the trials with $P$. crassirostris, it is assumed that the larvae will survive only if we provide suitable copepod as live feed. An experiment was carried out to identify the size preference in relation to growth of larvae or mouth gape. In this trial, 750 newly hatched larvae from the subsequent batch were introduced into a FRP tank of $1 \mathrm{t}$ capacity having $0.75 \mathrm{t}$ green water. The copepod $P$. crassirostris were introduced into the tank with adult copepod density maintained at a rate of 1 ind. $\mathrm{mL}^{-1}$, copepodites 2 ind. $\mathrm{mL}^{-1}$ and nauplii 4 ind. $\mathrm{mL}^{-1}$ throughout the trial by adding the required quantity of copepod stages after the daily population assessment at morning and evening by serial filtration (Anzeer et al., 2018). Larval mouth gape and feed preference were observed by periodic sampling. The feed size preference at each stage of the larval development was tracked by observing the gut contents of the larvae from 3rd day onwards up to $25 \mathrm{dph}$. Daily 10 ind. of larvae were anesthetized using sodium bicarbonate buffered MS-222, dissected and observed under Leica S8APO stereo zoom microscope and photographed under Zeiss AXIO Lab A1 compound microscope with Zeiss AxioCamERc5s camera with ZEN 2 lite software. From the photographs, size of copepods which were present in the gut was measured and the stages of the copepods were identified from the body parts and appendages.

Mouth gape was assessed using the lateral view method described by Shirota (1970) using Pythagorean Theorem, assuming that the jaws represent two sides of a right angled triangle and the hypotenuse, the expected mouth gape. The length from anterior-most point of the premaxilla to the posterior edge of the maxilla was considered as the upper jaw length. The length between anterior-most part of the mandible to its posterior edge were measured as the lower jaw length. The mouth gape in relation to age of larvae is graphically represented.

\subsection{Protocols for larval rearing of D. carneus}

Four subsequent trials were carried out using the larvae from subsequent batches to finalize the larval rearing protocols. 750 newly hatched larvae from the subsequent batch were introduced into a FRP tank of $1 \mathrm{t}$ capacity having $0.75 \mathrm{t}$ green water. $P$. crassirostris of required size were used at each stage of larvae. Sufficient numbers of different stages of copepods were made available in the rearing tanks by the process of serial filtration using different combinations of sieves of size $35 \mu \mathrm{m}, 60 \mu \mathrm{m}, 100 \mu \mathrm{m}$ and $170 \mu \mathrm{m}$. During the filtration, for all copepodites and adult stages, the sieve with smaller mesh $(35 \mu \mathrm{m})$ was used to collect all the smaller stages back to the mass culture tank (Anzeer et al., 2018). Copepod density 2 ind. $\mathrm{mL}^{-1}$ was maintained till $25 \mathrm{dph}$. Artemia nauplii (enriched by feeding $N$. oculata and I. galbana) were fed at a rate of 0.4 to 0.5 ind. $\mathrm{mL}^{-1}$ from $25 \mathrm{dph}$ to $50 \mathrm{dph}$. Pelleted feed of $500 \mu \mathrm{m}$ size started from $33 \mathrm{dph}$ onwards.

\subsection{Larval development}

Larval developmental stages were photographed and measurements were taken using a Leica S8APO stereo zoom microscope attached with Leica DFC 290 camera and software Leica application suite version 4.1.0 and Zeiss AXIO Lab A1 compound microscope attached with Axio Cam ERc5s with ZEN 2 lite software. To study the larval developments, 5 larvae were taken from the rearing tanks and were anesthetized using sodium bicarbonate buffered MS-222. For assessing the growth, linear measurements like total length, standard length, head length, body depth and eye diameter were also recorded. Observations on post hatch larvae for its development and changes in the pigmentation continued until complete metamorphosis into juveniles ( $40-50 \mathrm{dph}$ ). Photographs of newly hatched larvae were taken at an interval of $24 \mathrm{~h}$ up to $17 \mathrm{dph}$, from $20 \mathrm{dph}$ to $50 \mathrm{dph}$ at an interval of 5 days. Late larval stages and juveniles were photographed using digital cameras (Nikon D7100 \& Nikon D90).

\subsection{Nursery rearing}

The fully metamorphosed larvae were gently transferred after acclimatization into $500 \mathrm{~L}$ HDPE tanks with $250 \mathrm{~L}$ filtered seawater with a biological filter in the middle. Each tank was stocked with 20 juveniles and were fed daily 2 times using artificial pellets and boiled mussel meat.

\section{Results and discussion}

\subsection{Breeding pair formation and breeding behaviour}

After 4 months of rearing, fishes began to show breeding behaviour. Males started showing territorial behaviour and pair formation. Dominant male starts to chase other males and immature females. This behaviour is the primary indication of sexual maturity. As the male becomes extremely aggressive, it is ideal to keep only one male and female combination in the breeding tanks. $D$. carneus has been reported as functional, diandric protogynous hermaphrodite. Only the largest fish in the colony becomes functional male and second largest fish becomes functional female in the wild. (Asoh and Yoshikawa, 2003). Though smaller mature males were reported to coexist in wild, Asoh and Yoshikawa (2003) did not relate their presence in the colony to a chance of sneak fertilization. In case of its congeners like $D$. reticulatus (Schwarz and Smith, 1990) and D. aruanus (Fricke and Holzberg, 1974; Coates, 1982; Cole, 2002) mature smaller males were never noticed in the colony.

Cleaning the substratum, sudden changes in the behaviour and dancing movements of the male indicate breeding behaviour (Hattori and Casadeva, 2016). If the female is ready, it becomes conspicuously darker in colour. In general, courtship behaviour start by 'signal jump' (Tanaka, 1999) of male i.e., upward and downward swimming movement of male to attract its mate (Fig. 1a). Circular movements around the substratum and vigorous cleaning is also noticed during this phase (Fig. 1b). Frequent crossing movement and rubbing side by side is the clear indication for attracting the pair (Fig. 1c, d). Pairing and resting side by side (Fig. 1e) was observed after completion of pair formation. Both male and female positioned and move side by side in the same direction was observed during spawning (Fig. 1f). Randall and Allen (1977) reported similar courtship behaviour in D. carneus from islands of western Indian Ocean. Reproductive behaviour of $D$. carneus is very similar to that of $D$. aruanus, reported by Chlupaty (1957), Fishelson (1964) and Sale (1970) and D. albisella by Stevenson (1963) and Asoh 


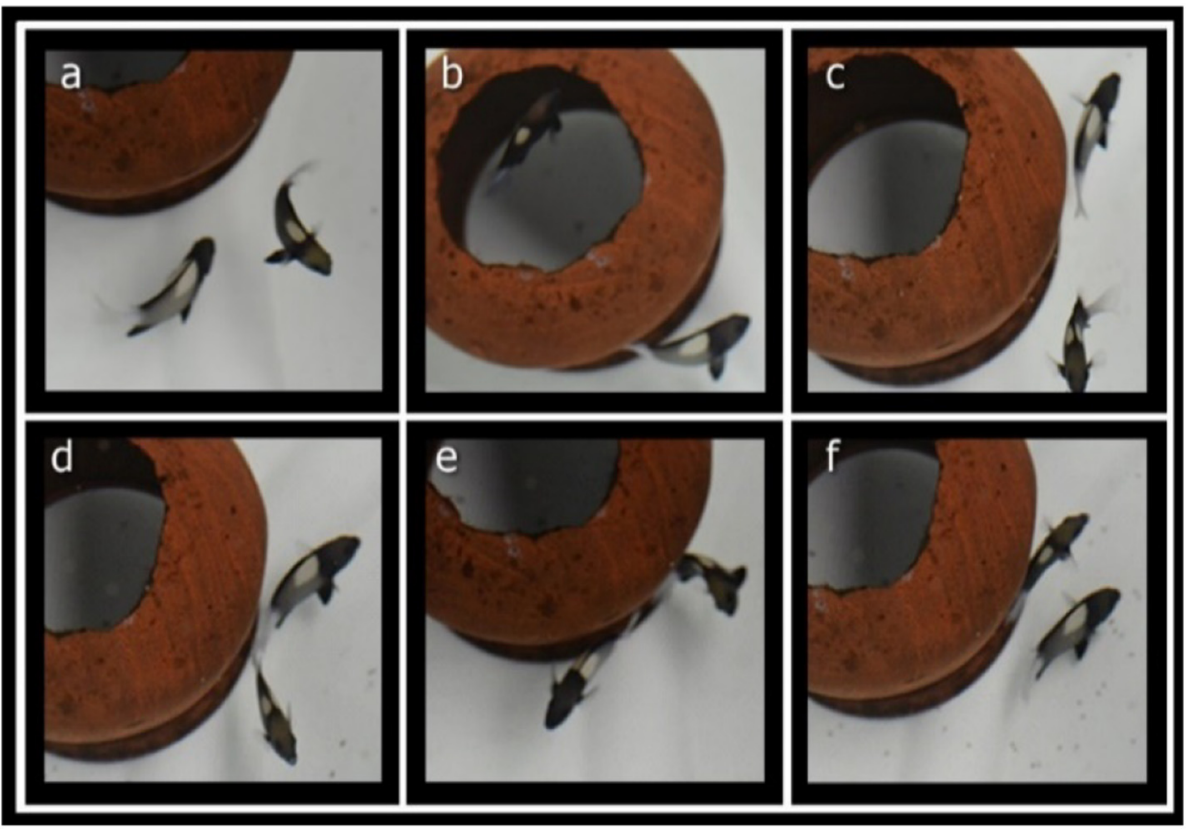

Fig. 1. Breeding behaviour of $D$. carneus in breeding tank around the artificial substratum (pots) kept for spawning; (a) 'signal jump' (upward and downward movement of male), (b) male making substratum ready, (c, d) crossing movements, (e) initiated pairing, (f) positioned for spawning.

and Yoshikawa, (2003). Tanaka (1999) also reported similar breeding behaviour for $D$. aruanus, $D$. trimaculatus, $D$. melanurus and $D$. reticulatus in aquaria. According to Wickler (1967), the breeding behavior within the genus has been found to be similar and unique.Dominant males selected for breeding trials were $50-65 \mathrm{~mm}$ in standard length, $20-25 \mathrm{~mm}$ in body depth and 8-9.7 $\mathrm{g}$ in weight. Females selected were $35-45 \mathrm{~mm}$ in standard length, $25-27 \mathrm{~mm}$ in body depth and $5.0-5.5 \mathrm{~g}$ in weight. D. carneus needs a substratum like earthen pot for spawning. Males spent most of their time for cleaning the pot for attaching the eggs.

\subsection{Spawning}

Observations were made from different breeding pairs. All spawning occurred early in the morning around 5 am and in some cases, it extended up to $10 \mathrm{am}$. This is very common in other pomacentrid fishes also (Suzuki et al., 1985; Olivotto et al., 2003; Gopakumar et al., 2009b; Rohini Krishna et al., 2016). Eggs were attached to the outer surface of the pot evenly as a single layer (Fig. 2). Male protected the territory and guarded the eggs, fanning was done by both male and female but in case of female it was not frequent. During the incubation, both the parents were aggressive and tried to attack even the siphoning tubes. Number of eggs per spawning varies from 6500 to 10,500. Sreeraj (2002), Gopakumar et al. (2009b) and Randall and Allen (1977) reported 5000-6000 eggs per spawning for $D$. carneus. Cobb (1975) reported the spawning of $D$. carneus in aquarium with a range of 5900-8260 eggs in each spawning. Under hatchery conditions, spawning of $D$. carneus was observed in almost all the months and peak spawning frequency was seen from September to June. Breeding pair continuously spawned for 2 months at an interval of 7-15 days. Sreeraj (2002) reported continuous spawning of D. carneus mostly at an interval of 12 days. In $D$. albisella spawning was reported throughout the year with a peak during the month of June by Stevenson (1963) and June to September by Asoh and Yoshikawa (2003). Tanaka (1999) reported continuous spawning for 7-10 months in four species of damsel fishes. The interval of consecutive spawning was reported as 8-15 days for $D$. aruanus, $10-13$ days for $D$. trimaculatus, 5-7 days for $D$. melanurus and 9-13 days for $D$. reticulatus. Average spawning periodicity of $D$. aruanus and $D$. trimaculatus was reported as 14 days by Gopakumar

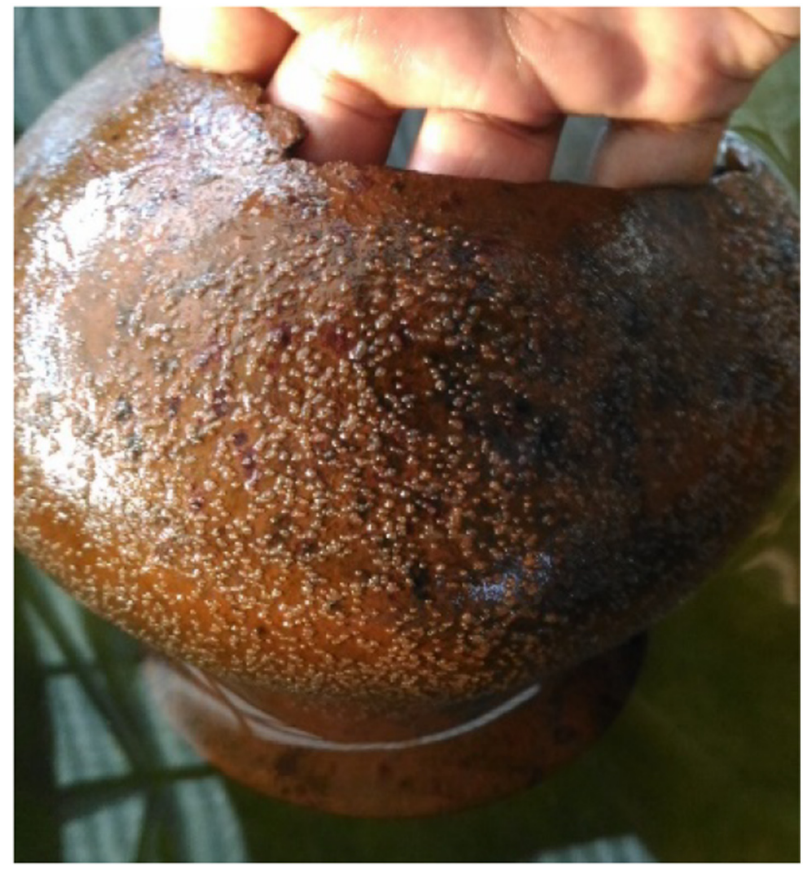

Fig. 2. Eggs of D. carneus on substratum (clay pot) before hatching.

et al. (2009a).

\subsection{Nature of the eggs and its development}

Eggs (Fig. 3a-s) were elliptical and were almost uniform size in each spawning. Marked variations in size of eggs were observed in the same breeding pair over the total breeding season. The egg size was smaller in the beginning and towards the end of breeding cycle and egg size was largest towards the middle of the breeding cycle. Size of largest eggs recorded were $754.30 \pm 10.81 \mu \mathrm{m}$ in length and $534.01 \pm 24.06 \mu \mathrm{m}$ width. Size of smallest eggs recorded were $669.77 \pm 15.08 \mu \mathrm{m}$ in length and $490.04 \pm 13.6 \mu \mathrm{m}$ in width. Sreeraj (2002) reported eggs of 


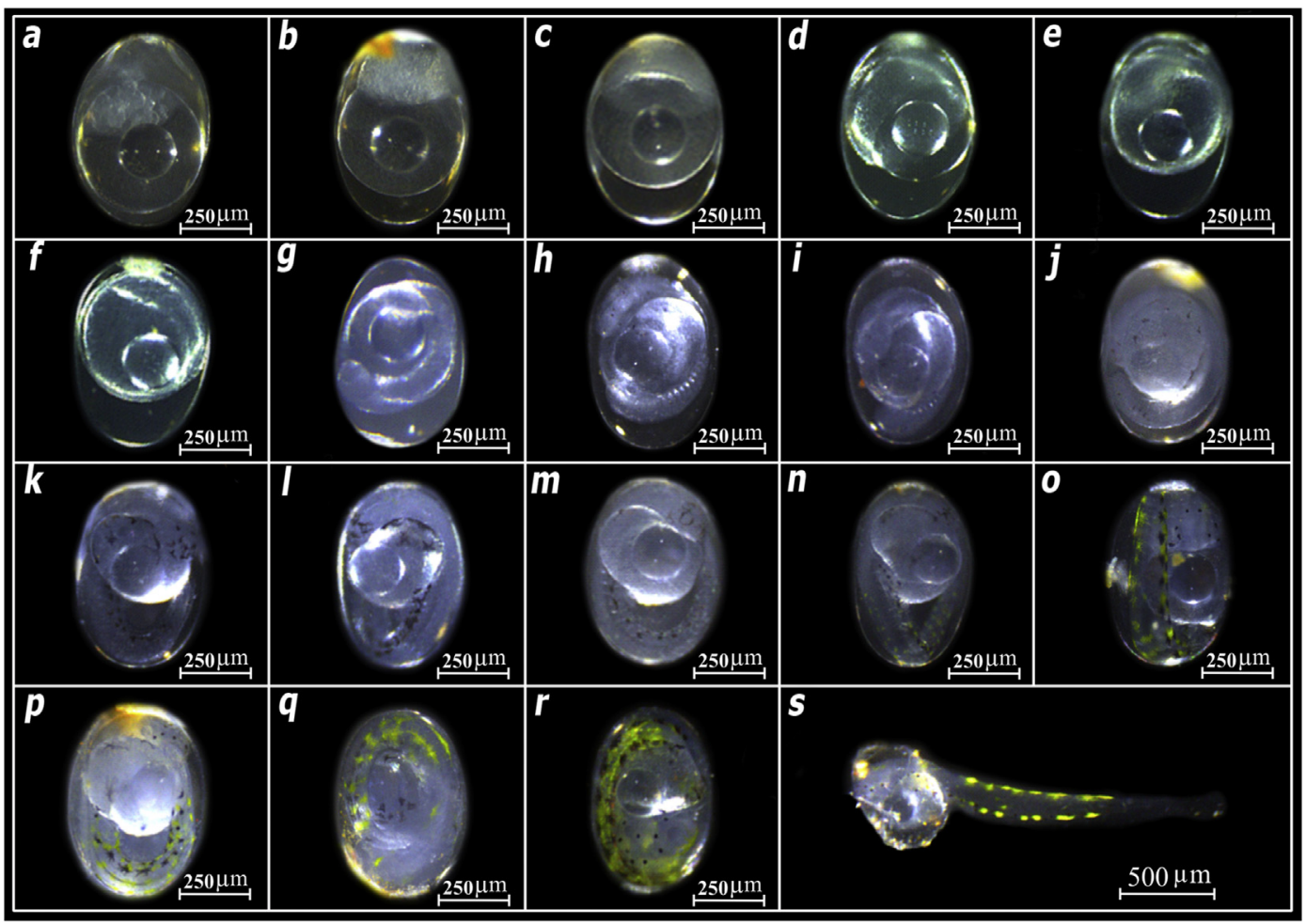

Fig. 3. Embryonic development of eggs of $D$. carneus till hatching. Scale bar as indicated in respective figures. (a) $1 \mathrm{hpf}-32$ celled stage, (b) $2.5 \mathrm{hpf}$ - morula stage, (c) $3 \mathrm{hpf}$ - blastula stage, (d) $6 \mathrm{hpf}$ - gastrula stage, (e) $9 \mathrm{hpf}$ - blastopore closing, (f) $10 \mathrm{hpf}$ - development of embryonic axis, (g) $15 \mathrm{hpf}$ - larval somites started appearing, (h) $19 \mathrm{hpf}$ - non pigmented primitive eye, (i) $20 \mathrm{hpf}$ - scattered yellowish-green pigments appeared, (j) $24 \mathrm{hpf}$ - melanophores became more visible and tail detachment initiated, (k) $30 \mathrm{hpf}$ - melanophores expanded to the stellated stage, (l), $32 \mathrm{hpf}$ - larval movements initiated. (m) 35 hpf - yellowish-green pigments became conspicuous, (n) $41 \mathrm{hpf}$ - tail and trunk got thickened, (o) $48 \mathrm{hpf}$ - green pigmentation and melanophores became more prominent, By (p) 55 hpf - embryo started to wriggle inside egg shell, (q) $58 \mathrm{hpf}$ - tail twitching movements initiated, (r) $60 \mathrm{hpf}$ - ready to hatch and the larvae started moving vigorously (s) 61 hpf - Egg shell broke near the tail and the head remains inside the shell for a while. (For interpretation of the references to colour in this figure legend, the reader is referred to the web version of this article.)

D. carneus having length $670 \pm 0.002 \mu \mathrm{m}$ and width $450 \pm 0.0015 \mu \mathrm{m}$ from the same locality. Gopakumar et al. (2009b) reported egg size of $D$. carneus from 625 to $650 \mu \mathrm{m}$. In general, eggs of fishes of the genus Dascyllus are smaller than most of the other genera in the family Pomacentridae. Tanaka (1999) reported that the size of egg of $D$. aruanus ranged from 700 to $780 \mu \mathrm{m}$ in length and width ranged from 480 to $530 \mu \mathrm{m}, D$. trimaculatus length from 600 to $650 \mu \mathrm{m}$ and width from 450 to $480 \mu \mathrm{m}, D$. melanurus, length ranged between 650 and $680 \mu \mathrm{m}$ and width from 430 to $450 \mu \mathrm{m}$ and for $D$. reticulatus length varied from 630 to $650 \mu \mathrm{m}$ and width from 480 to $500 \mu \mathrm{m}$. The eggs in D. albisella were of $800 \mu \mathrm{m}$ in length and $400 \mu \mathrm{m}$ in width (Stevenson, 1963).

Morphological details of eggs of $D$. carneus closely resemble the description of eggs of other Dascyllus spp. reported by Tanaka (1999). The eggs were transparent and slowly become translucent during the late hours of incubation. The egg case was flexible and smooth in appearance. A peripheral stalk by which the eggs get attached to the substratum was present at the animal pole and the stalk was pale yellow in colour. The egg clutches comprised of eggs at different stages, which may be due to the variation in the time of fertilization. Better survival was observed in larvae developed from larger eggs even though; the size range of eggs varies considerably.

The eggs reached 32 celled stage (Fig. 3a) within $2 \mathrm{~h}$ post fertilization (hpf). Morula stage (Fig. 3b) observed by $2.5 \mathrm{hpf}$ and blastula stage (Fig. 3c) has started after $3 \mathrm{hpf}$. Eggs developed into the gastrula stage by 6 hpf. Gastrula stage (Fig. 3d) ended by 9 hpf, blastoderm started covering the yolk sac and blastopore closed by the end of $9 \mathrm{hpf}$ (Fig. 3e). Development of embryonic axis (Fig. 3f) was observed at 10 hpf. By $15 \mathrm{hpf}$, the larval somites started appearing (Fig. 3g).
Development of head region and a non-pigmented primitive eye were observed at $19 \mathrm{hpf}$ (Fig. 3h). Scattered yellowish-green pigments appeared from $20 \mathrm{hpf}$ (Fig. 3i). By $24 \mathrm{hpf}$ (Fig. 3j), melanophores became more visible and tail detachment initiated. Further, melanophores expanded to the stellated stage and spread over the yolk by $30 \mathrm{hpf}$ (Fig. 3k). At 32 hpf (Fig. 31), stellate and expanded melanophores extended along the ventral region of notochord and larval movements initiated. Yellowish-green pigments became conspicuous by $35 \mathrm{hpf}$ (Fig. 3m). Up to $41 \mathrm{hpf}$ (Fig. 3n), the embryo growth continued, tail and trunk got thickened and green pigments appeared clearer. After this stage, larval movements inside the egg became more vigorous. By 48 hpf (Fig. 3o), the dorsal and ventral margins of embryos trunk showed extensive green pigmentation and melanophores also expanded. By 55 hpf (Fig. 3p) embryo occupied the entire area of the egg, started to wriggle inside the shell. Twitching movements of tail was noticed from 58 hpf (Fig. 3q). By 60 hpf (Fig. 3r), the eggs were ready to hatch and the larvae now started to move inside eggshell vigorously. Sreeraj (2002) reported similar events in development of eggs of $D$. carneus in captivity. The embryonic development of $D$. aruanus, $D$. trimaculatus, $D$. melanurus and $D$. reticulatus reported were similar to that of $D$. carneus but the time periods for various events were lengthier in all species except $D$. aruanus reported by Tanaka (1999).

\subsection{Hatching}

In the larval rearing tanks, hatching occurred in the late evening after sunset on $61-65 \mathrm{~h}$ of incubation. Egg shell broke near the tail and the head remained inside the shell for a while (Fig. 3s). Almost similar incubation period was reported by Sreeraj (2002) for D. carneus but 


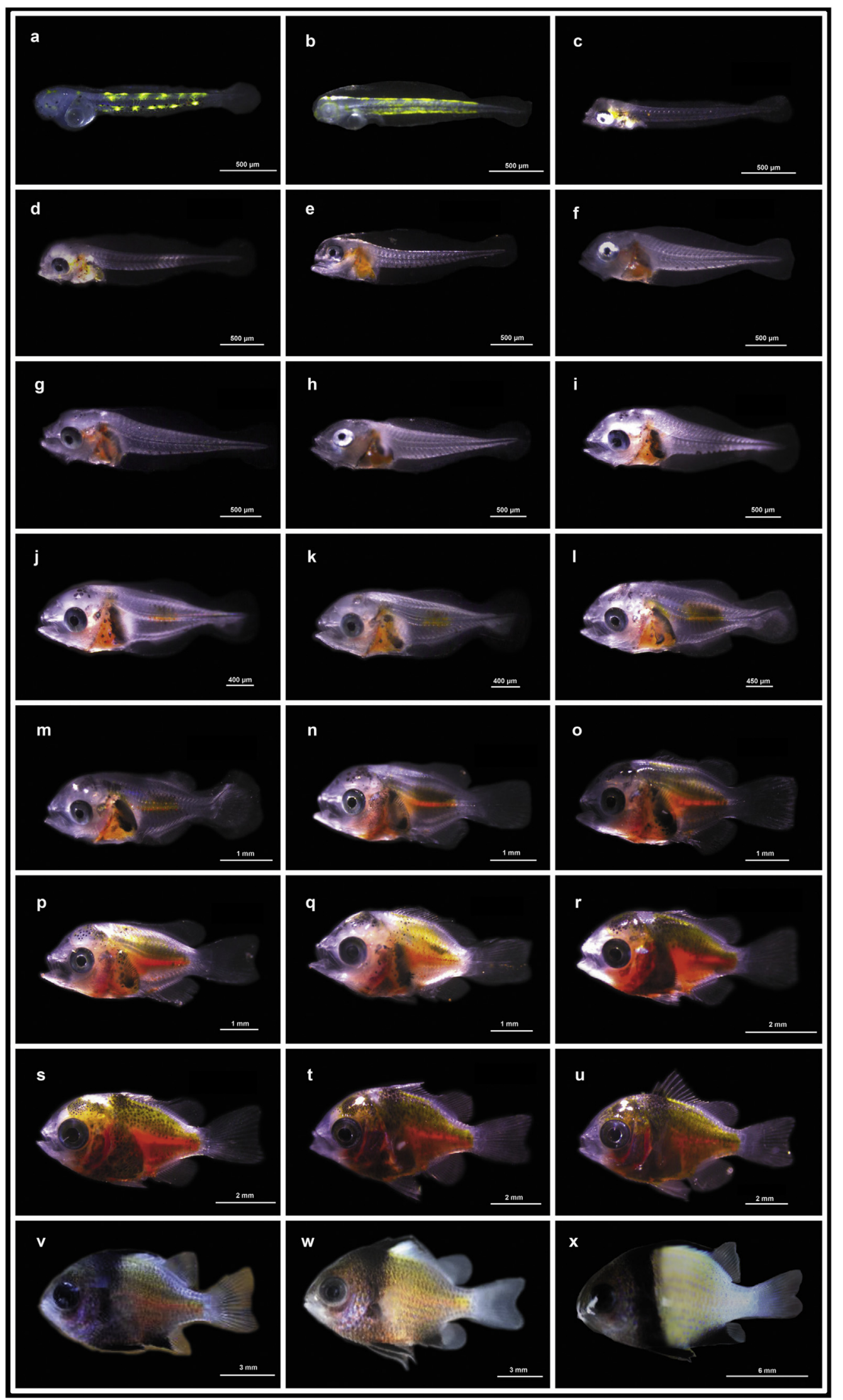

Fig. 4. The early larval development of D. carneus. Shown are multiple individuals taken from the same batch of larvae. Scale bar as indicated in respective figures. (a) A newly hatched larva, (b)1 dph larva, (c) 2 dph larva, (d) 3 dph larva, (e) 4 dph larva, preflexion stage begins (f) 5 dph larva, (g) $6 \mathrm{dph}$ larva, (h) 7 dph larva, (i) 8 dph larvae, (j) 9 dph larva, (k) 10 dph larva, (1)11 dph larva showing flexion stage, (m)12 dph larva showing flexion stage, (n)13 dph larva postflexion stage begins, (o)14 dph larva, (p)15 dph larva; postflexion completed, (q) $17 \mathrm{dph}$ larva, in transition stage, (r) 20 dph larva, (s) 25 dph larva, (t) 30 dph larva in juvenile stage and squamation begins (u) 35 dph larva, (v) 40 dph larva (w) 45 dph larva, juveniles (x) 50 dph fully formed juvenile. 
Cobb (1975) reported the incubation period as $48 \mathrm{~h}$ in a temperature range of $26-30{ }^{\circ} \mathrm{C}$. In case of $D$. aruanus, $D$. trimaculatus, $D$. melanurus and $D$. reticulatus reported by Tanaka (1999), the hatching periods were $65,77,86$, and $87 \mathrm{~h}$ respectively.

Hatching rates observed during present study was 90.6 to $98.81 \%$. Danilowicz and Brown (1992) reported hatching rates as $100 \%$ for $D$. albisella and $80 \%$ for $D$. aruanus. The larvae were pelagic and spread all over the water column. Very low level aeration was provided to avoid entrapment of larvae in the air bubbles and surface of water because the larvae at pre-larval stages were very weak and tend to stick on bubbles and water surface.

\subsection{Larval development}

Newly hatched larvae (Fig. 4a) were small, pelagic and distributed evenly in the water column. Total length was $1.95 \pm 0.14 \mathrm{~mm}$; standard length $1.75 \pm 0.04 \mathrm{~mm}$ and it is the smallest larvae reported among Dascyllus spp. Body depth was measured as $0.18 \pm 0.01 \mathrm{~mm}$ and optic vesicle diameter was $0.15 \pm 0.005 \mathrm{~mm}$. The total length of newly hatched larvae of $D$. carneus was much smaller $(1.4 \mathrm{~mm})$ as reported by Cobb (1975). Newly hatched larvae of other Dascyllus species of damsel fishes like $D$. aruanus, $D$. trimaculatus, $D$. melanurus and $D$. reticulatus were in the range of 2.08 to $2.50 \mathrm{~mm}$ (Tanaka, 1999) for $D$. albisella it was $2.5 \mathrm{~mm}$ (Stevenson, 1963) and for D. albisella and D. aruanus it was $2.2 \mathrm{~mm}$ (Danilowicz and Brown, 1992). In $1 \mathrm{dph}$ larvae (Fig. 4b), the total length was measured as $2.28 \pm 0.03 \mathrm{~mm}$, standard length measured as $1.86 \pm 0.03 \mathrm{~mm}$, head length $0.36 \pm 0.02 \mathrm{~mm}$, body depth $0.16 \pm 0.002 \mathrm{~mm}$ and eye diameter $0.17 \pm 0.003 \mathrm{~mm}$. Yolk sac and oil globule were measured $0.12 \pm 0.01 \mathrm{~mm}$ and $0.2 \pm 0.01 \mathrm{~mm}$ respectively. Tanaka, (1999) reported length range of 1 dph larvae from 2.38 to $2.63 \mathrm{~mm}$ for $D$. aruanus, $D$. trimaculatus, $D$. melanurus and $D$. reticulatus. Average total length of 2 dph larvae (Fig. 4c) was $2.27 \pm 0.2 \mathrm{~mm}$, standard length $1.95 \pm 0.002 \mathrm{~mm}$; head length $0.38 \pm 0.01 \mathrm{~mm}$, eye diameter, $0.2 \pm 0.01 \mathrm{~mm}$ and body depth $0.22 \pm 0.01 \mathrm{~mm}$. Mouth opening was noted $28 \mathrm{~h}$ after hatching and eyes became functional. Yolk sac measured $0.10 \pm 0.01 \mathrm{~mm}$. The 3 dph larvae (Fig. 4d) measured $2.43 \pm 0.04 \mathrm{~mm}$ in total length, $2.3 \pm 0.02 \mathrm{~mm}$ in standard length, $0.45 \pm 0.0172 \mathrm{~mm}$ in head length, $0.23 \pm 0.01 \mathrm{~mm}$ in body depth and eye diameter was $0.19 \pm 0.004 \mathrm{~mm}$. The external body colouration started appearing. Unlike the present case, Tanaka, (1999) reported a reduction Tanaka (1999) reported a reduction in length range $(2.0-2.18)$ for $D$. aruanus, $D$. trimaculatus, D. melanurus and D. reticulatus in 2nd and 3rd day. In $D$. carneus, yolk and oil globule were completely absorbed by third day as in the case of most of the other damsel species reported (Alshuth et al., 1998; Tanaka, 1999).

Preflexion stage of larvae was observed from $4 \mathrm{dph}$ to $10 \mathrm{dph}$. The 4 dph larvae (Fig. 4e) were $2.47 \pm 0.02 \mathrm{~mm}$ in total length, $2.33 \pm 0.03 \mathrm{~mm}$ in standard length, head length of $0.5 \pm 0.020 \mathrm{~mm}$, $25 \pm 0.01 \mathrm{~mm}$ in body depth and eye diameter was $0.23 \pm 0.01 \mathrm{~mm}$. Tanaka (1999) reported a reduction in length range (2.012-2.15) in all four species $D$. aruanus, $D$. trimaculatus, $D$. melanurus and $D$. reticulatus consecutively in fourth day also. In 5 dph larvae (Fig. 4f), total length measured was $2.53 \pm 0.02 \mathrm{~mm}$, standard length $2.37 \pm 0.01 \mathrm{~mm}$, head length $0.63 \pm 0.02 \mathrm{~mm}$, body depth $0.3 \pm 0.02 \mathrm{~mm}$, eye diameter $0.22 \pm 02 \mathrm{~mm}$ indicating marked increase in all measurements except eye diameter. Tanaka (1999) reported increase of total length from 2.28 to $2.48 \mathrm{~mm}$ in $D$. trimaculatus of similar age group. The $6 \mathrm{dph}$ larvae (Fig. 4g) measured $2.69 \pm 0.03 \mathrm{~mm}$ in total length, $2.55 \pm 0.06 \mathrm{~mm}$ in standard length, $0.78 \pm 0.02 \mathrm{~mm}$ in head length, $0.36 \pm 0.01 \mathrm{~mm}$ in body depth and eye diameter was $0.28 \pm 0.02 \mathrm{~mm}$ indicating marked increase in all measurements than $5 \mathrm{dph}$. Tanaka (1999) reported that the larval development of $D$. aruanus, D. reticulatus and $D$. trimaculatus up to 5 days and $D$. melanurus up to 4 days only. There has been no report about the larval description of any of the Dascyllus spp. beyond $5 \mathrm{dph}$. The $7 \mathrm{dph}$ larvae (Fig. 4h) measured
$2.97 \pm 0.02 \mathrm{~mm}$ in total length, $2.73 \pm 0.04 \mathrm{~mm}$ in standard length, $0.83 \pm 0.02 \mathrm{~mm}$ in head length, $0.43 \pm 0.02 \mathrm{~mm}$ in body depth and eye diameter was $0.29 \pm 0.06 \mathrm{~mm}$. The fin fold at the sagittal plane slightly reduced at the dorsal area. The $8 \mathrm{dph}$ larvae (Fig. $4 \mathrm{i}$ ) measured $3.09 \pm 0.07 \mathrm{~mm}$ in total length, $2.85 \pm 0.01 \mathrm{~mm}$ in standard length, $0.91 \pm 0.02 \mathrm{~mm}$ in head length, $0.8 \pm 0.01 \mathrm{~mm}$ in body depth and eye diameter was $0.35 \pm 0.01 \mathrm{~mm}$. Orange pigmentation became more prominent in abdominal area. The 9 dph larvae (Fig. 4j) measured $3.31 \pm 0.04 \mathrm{~mm}$ in total length, $3.13 \pm 0.09 \mathrm{~mm}$ in standard length, $1.05 \pm 0.05 \mathrm{~mm}$ in head length, $0.96 \pm 0.06 \mathrm{~mm}$ in body depth and eye diameter was $0.37 \pm 0.01 \mathrm{~mm}$. Caudal peduncle depth was $0.19 \pm 0.002 \mathrm{~mm}$. Hypural plates began to develop. Orange pigments were randomly distributed externally at the lateral middle regions of the notochord. The $10 \mathrm{dph}$ larvae (Fig. $4 \mathrm{k}$ ) measured $3.49 \pm 0.09 \mathrm{~mm}$ in total length, $3.18 \pm 0.01 \mathrm{~mm}$ in standard length, $1.08 \pm 0.02 \mathrm{~mm}$ in head length, $1.07 \pm 0.02 \mathrm{~mm}$ in body depth and eye diameter was $0.42 \pm 0.01 \mathrm{~mm}$. Caudal rays developed further, sagittal fin fold reduced and the caudal peduncle region began to develop.

Flexion stage of larvae was from $11 \mathrm{dph}$ to $12 \mathrm{dph}$. Larvae of 11 day (Fig. 4l) measured $3.76 \pm 0.05 \mathrm{~mm}$ in total length, $3.46 \pm 0.06 \mathrm{~mm}$ in standard length, $1.24 \pm 0.02 \mathrm{~mm}$ in head length $1.23 \pm 0.04 \mathrm{~mm}$ in body depth caudal peduncle depth $0.33 \pm 0.01 \mathrm{~mm}$ and eye diameter was $0.43 \pm 0.01 \mathrm{~mm}$. In the flexion stage, caudal fin rays, dorsal fin anlage and anal fin anlage were further developed. Caudal peduncle region started developing and ventral fin buds were clearly visible. The $12 \mathrm{dph}$ larvae (Fig. $4 \mathrm{~m}$ ) measured $4.15 \pm 0.1 \mathrm{~mm}$ in total length, $3.6 \pm 0.21 \mathrm{~mm}$ in standard length, $1.22 \pm 0.19 \mathrm{~mm}$ in head length $1.31 \pm 0.03 \mathrm{~mm}$ in body depth, caudal peduncle depth $0.39 \pm 0.005 \mathrm{~mm}$ and eye diameter was $0.47 \pm 0.004 \mathrm{~mm}$. The dorsal melanophores at the head region began to develop further dorsally. The mid lateral region of the body showed stellate expanded melanophores and orange pigments. The notochord tip was in maximum upward position. Caudal fin rays became more visible. The fin fold through the sagittal plane disappeared. Dorsal fin rays began to develop.

Postflexion stage of the larvae was from $13 \mathrm{dph}$ to $15 \mathrm{dph}$. Larvae (Fig. $4 \mathrm{n}$ ) measured $4.53 \pm 0.08 \mathrm{~mm}$ in total length, $3.77 \pm 0.11 \mathrm{~mm}$ in standard length, $1.59 \pm 0.03 \mathrm{~mm}$ in head length $1.65 \pm 0.03 \mathrm{~mm}$ in body depth and eye diameter was $0.47 \pm 0.01 \mathrm{~mm}$. Dorsal fin rays and spines started to develop. Caudal peduncle has formed. Caudal fin rays ossification intensified. Anal fin rays and anal spine also further developed. The $14 \mathrm{dph}$ larvae (Fig. 4o) measured $4.92 \pm 0.03 \mathrm{~mm}$ in total length, $3.93 \pm 0.06 \mathrm{~mm}$ in standard length, $1.82 \pm 0.02 \mathrm{~mm}$ in head length $1.85 \pm 0.01 \mathrm{~mm}$ in body depth and eye diameter was $0.62 \pm 0.03 \mathrm{~mm}$. The ossification of caudal fin rays further progressed. The dorsal spines further developed at the anterior region. Anal fin developed and anal fin rays were clearly visible. On $15 \mathrm{dph}$, larvae (Fig. 4p) measured $5.07 \pm 0.05 \mathrm{~mm}$ in total length, $4.01 \pm 0.09 \mathrm{~mm}$ in standard length, $1.89 \pm 0.02 \mathrm{~mm}$ in head length $1.92 \pm 0.005 \mathrm{~mm}$ in body depth and eye diameter was $0.65 \pm 0.05 \mathrm{~mm}$. Deep orange pigmentation was noted almost throughout the body.

Transition stage of the larvae was from $16 \mathrm{dph}$ to $25 \mathrm{dph}$. On 17 day, larvae (Fig. 4q) measured $5.38 \pm 0.05 \mathrm{~mm}$ in total length, $4.29 \pm 0.03 \mathrm{~mm}$ in standard length, $2.04 \pm 0.04 \mathrm{~mm}$ in head length $1.96 \pm 0.05 \mathrm{~mm}$ in body depth and eye diameter was $0.68 \pm 0.01 \mathrm{~mm}$. Dorsal spines, dorsal fin rays, anal fin rays, ventral fin, caudal peduncle and caudal fin rays were well developed. The 20 dph larvae (Fig. 4r) measured $6.07 \pm 0.06 \mathrm{~mm}$ in total length, $4.63 \pm 0.01 \mathrm{~mm}$ in standard length, $2.17 \pm 0.02 \mathrm{~mm}$ in head length, $2.3 \pm 0.01 \mathrm{~mm}$ in body depth and eye diameter was $0.89 \pm 0.03 \mathrm{~mm}$. The base colour of larvae became olive green. All fin rays were well ossified at this stage. The $25 \mathrm{dph}$ larvae (Fig. 4s) measured $7.34 \pm 0.1 \mathrm{~mm}$ in total length, $5.57 \pm 0.05 \mathrm{~mm}$ in standard length, $2.45 \pm 0.02 \mathrm{~mm}$ in head length, $3 \pm 0.005 \mathrm{~mm}$ in body depth and eye diameter was $1.08 \pm 0.02 \mathrm{~mm}$. The upper half of the larva became olive green in colour decorated with more numbers of contracted punctate melanophores and the lower half was, more or less orangish in 
colour. Dorsal, ventral, anal and caudal fins were well developed. Caudal fin edge started becoming concave indicating the development of forked tip.

Juvenile stage started from $30 \mathrm{dph}$. The larvae (Fig. 4t) measured $8.42 \pm 0.1 \mathrm{~mm}$ in total length, $6.58 \pm 0.11 \mathrm{~mm}$ in standard length, $3.26 \pm 0.11 \mathrm{~mm}$ in head length, $3.59 \pm 0.02 \mathrm{~mm}$, in body depth and eye diameter was $1.24 \pm 0.02 \mathrm{~mm}$. Pigmentation remained almost same as the larvae of $25 \mathrm{dph}$ but the colour gradation thickens as it results in fading of melanophores. Dorsal spines are well developed. Squamation also started. The $35 \mathrm{dph}$ larvae (Fig. 4u) measured $9.55 \pm 0.1 \mathrm{~mm}$ in total length, $7.41 \pm 0.22 \mathrm{~mm}$ in standard length, $3.34 \pm 0.02 \mathrm{~mm}$ in head length, $3.93 \pm 0.04 \mathrm{~mm}$ in body depth and eye diameter was $1.42 \pm 0.03 \mathrm{~mm}$. Body was deep red coloured with a greenish tint dorsally above the lateral line. All the fins and fin rays were well developed and similar to that of the adults.

The $40 \mathrm{dph}$ larvae (Fig. 4v) continued metamorphosis. Body became darker in the anterior half with pale yellow and orange colour in the posterior half. Most of scales were with one or more small fluorescent blue dots. Lips became blue and basal portion of body scales were slightly dusky. The black bar from base of the dorsal fin to base of pelvic fin became more prominent. Caudal fin was light yellow in colour. The anterior part of the dorsal fin, pelvic fin and anterior part of anal fin were black in colour. The $45 \mathrm{dph}$ larvae (Fig. 4w) measured $12 \pm 0.12 \mathrm{~mm}$ in total length, standard length $10.9 \pm 0.2 \mathrm{~mm}$ and body depth $6.45 \pm 0.13 \mathrm{~mm}$. Eye diameter was $1.67 \pm 0.8 \mathrm{~mm}$. Head length was measured as $3.87 \pm 0.02 \mathrm{~mm}$. Pelvic fin length was $1.29 \pm 0.11 \mathrm{~mm}$. Dorsal fin length was $2.58 \pm 0.1 \mathrm{~mm}$. The metamorphosis of all the larvae of $D$. carneus into juvenile was completed by $50 \mathrm{dph}$. At this stage, juveniles (Fig. 4x) were light yellowish in colour with a dark band behind the head. Numerous diffused blackish and deep blue coloured patches and spots were visible on the head. Almost all lighter scales were with fluorescent blue dots or lines. Danilowicz and Brown (1992) reported metamorphosis of larvae of $D$. albisella from 23 to 45 days and $D$. aruanus from 30 to 50 day in different feeding trials. Gopakumar et al. (2009a) reported metamorphosis of damsel fishes like $D$. trimaculatus as 35-40 days, $D$. aruanus as 25-31 days, Pomacentrus caeruleus as 17-21 days, Chromis viridis as 30-49 days, $N$. nemurus as 16-21 days. In regal demoiselle (Neopomacentrus cyanomos), metamorphosis was completed from 28 to 32 days (Setu et al., 2010; Rohini Krishna et al., 2016). In sergeant major (Abudefduf saxatilis), metamorphosis was completed by 32 days (Alshuth et al., 1998). Metamorphosis of $C$. atripectoralis larvae was completed in 21-25 days (Kavanagh and Alford, 2003) and of P. amboinensis in 20-22 days (Kavanagh and Alford, 2003; Murphy et al., 2007). Gopakumar et al. (2002) reported the period of metamorphosis in larvae of $N$. nemurus, $P$. caeruleus and $N$. filamentosus as 30 to 40 days.

Knowledge on early development of larvae is essential for confirmation of critical periods of first feeding, mortality, malformation and nutritional needs and environmental requirements. Critical periods often overlap with major events in ontogeny such as initiation of flexion (preflexion), flexion period, transition stage and final metamorphosis (Kovac and Copp, 1999; Battaglene and Cobcroft, 2007; Somarakis and Nikolioudakis, 2010). In case of $D$. carneus also critical days of survival observed was observed in 3-4 dph, 9-10 dph and 14-15 dph. Linear growth measurement chart of larvae for total length, standard length, head length, body depth and eye diameter up to $35 \mathrm{dph}$ is represented in Fig. 5. Trends in all the measurements except eye diameter changes its phase after all the three critical periods. Growth was maximum after postflexion stage (15 dph). Steady increase in length was noticed in daily growth graph of $D$. carneus from the postflexion period onwards and continued beyond juvenile stage. Somarakis and Nikolioudakis (2010) indicated notochord flexion stage as a 'developmental milestone in the early life history' of fishes. In this stage, the organogenesis and differentiation was maximum and faster growth is essential to have early settlement, schooling and metamorphosis. Steady and fast growth is observed in D. carneus also after postflexion stage i.e., after $15 \mathrm{dph}$

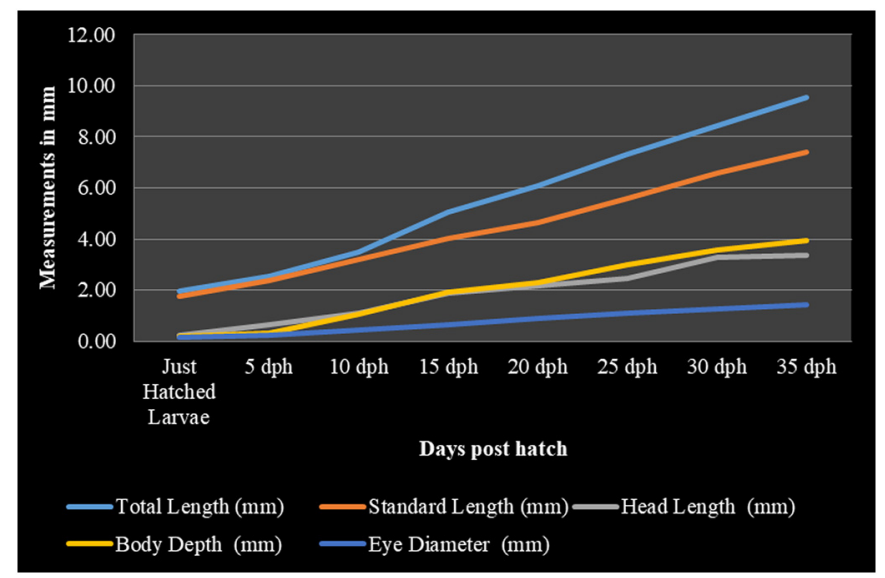

Fig. 5. Increase in linear measurements of $D$. carneus larvae $(n=5)$ during larval rearing.

and beyond the juvenile stage.

\subsection{Optimisation of feeding}

\subsubsection{Identification of feed preference}

Since there was no information available on larval rearing of this species, the first few trials were undertaken to identify feed preferences of the larvae. Larval survival was obtained in both the trials where nauplii of copepod $P$. crassirostris were used as first feed. One-sample Chi-Square test indicated significant difference $(p<.01)$ among the survival on 5th day, 10th day and 15th day. No survival was observed beyond 5th day in the tanks where only rotifers were used for feeding. Maximum survival was obtained in the tank where only copepods were used as first feed. Results are graphically represented (Fig. 6). Larvae of $D$. aruanus and $D$. trimaculatus also could not consume rotifer for first feeding (Gopakumar et al., 2009b). In the trials with a combination of nauplii of $P$. crassirostris and rotifer, the survival rate at 5 th day $(6.78 \%)$ and 10th day (6\%) was very low compared to those fed with copepods alone (51.67\% and $19.89 \%)$. By 15 th day there was no survival in tanks were the combination of feeds were used. This is because of the faster multiplication of unconsumed rotifer in the tanks which was also reported by Gopakumar et al. (2009b) during larval rearing of $D$. aruanus and $D$. trimaculatus. At the end of 15 days trial, final survival noticed as $2.56 \%$ in trials with $P$. crassirostris and beyond this period no mortality was observed. Analysis of the results clearly indicated that presence of copepods is important for the survival and growth of larvae of $D$.

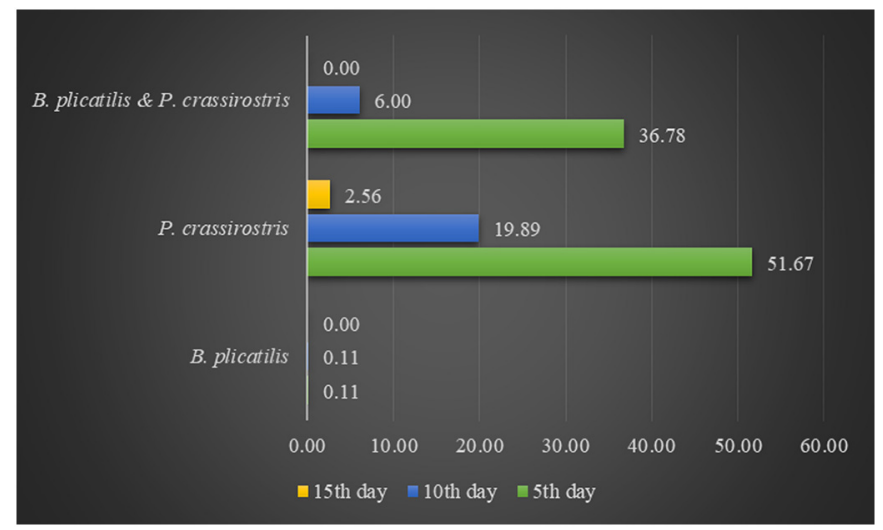

Fig. 6. Percentage survival of $D$. carneus larvae $(n=300)$ using different live feeds for 15 days; a combination of rotifer Brachionus plicatilis $\left(5 \mathrm{~mL}^{-1}\right)$ and copepod Parvocalanus crassirostris $\left(5 \mathrm{~mL}^{-1}\right)$, nauplii of $P$. crassirostris alone $\left(10 \mathrm{~mL}^{-1}\right)$ and $B$. plicatilis alone $\left(10 \mathrm{~mL}^{-1}\right)$. 


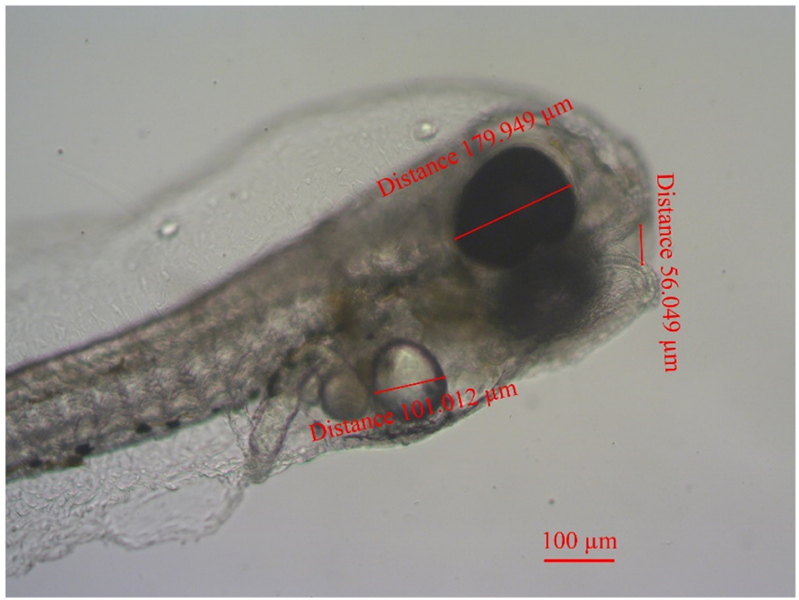

Fig. 7. Larval mouth opening of D. carneus at 28 th hour (1.16 dph).

carneus. It is also confirmed that copepods are essential as first feed for larvae. Brough et al. (2018) clearly indicated that the larvae of $D$. carneus are difficult to rear. This is true in case of almost all species of Dascyllus and survival was noticed only when the first feed used was copepod nauplii (Danilowicz and Brown, 1992: Gopakumar et al., 2009b). Trials with mixed feeding of copepod and rotifer failed to get survival after 15 days indicating that the rotifer could not support the feeding of larvae in later stages also. D. aruanus and D. trimaculatus larvae survived only when copepod alone was used as their first feed (Gopakumar et al., 2009a).

Copepods have a highly relevant and rich biochemical profile suited for the proper development of most of the marine fish larvae and highly unsaturated fatty acids such as DHA and EPA are present in the most appropriate ratios in copepods suitable for fish larval development (Sun and Fleeger, 1995; Stottrup and Norsker, 1997; Sargent et al., 1997; Olivotto et al., 2008). Consumption of these essential fatty acids can reduce the chances of morphological abnormalities of fish larvae (Satoh et al., 1989; Satoh and Takeuchi, 2009). Moreover, the characteristic moving pattern 'pause and move' of copepod nauplii makes them more vulnerable prey for initial feeding. Copepods can improve health, reduce abnormalities in growth, increase stress tolerance, enhance development and improve pigmentation and growth of fish larvae (Bell et al., 2003; Copeman et al., 2002; Olivotto et al., 2006a, 2006b, 2008; Vagelli, 2004).

\subsubsection{Mouth gape assessment}

Mouth opening (Fig. 7) was noticed at the age of $1.16 \mathrm{dph}$ (28th hour and mouth gape was measured as $0.1 \pm 0.04 \mathrm{~mm}$ which subsequently increased into $1.08 \pm 0.08 \mathrm{~mm}$ by $17 \mathrm{dph}$. The measurements were graphically represented (Fig. 8). Larval mouth gape is an important measure of prey size (Shirota, 1970; Munk, 1997; Planas and Cunha, 1999; Ostergaard et al., 2005; Yúfera and Darias, 2007; Carassou et al., 2009). Shirota (1970) reported that the prey size would go up to $50 \%$ of the mouth gape, if the larvae could fully expand its lower and upper jaws. Larval fishes having small mouth size, feed mainly on phytoplankton, protozoa and the nauplii of small copepods. Among these, copepod nauplii forms the major food for first feeding of many marine fish larvae (Llopiz and Cowen, 2009; Sampey et al., 2007; Burgess and Callan, 2018).

\subsubsection{Prey size observations}

Larval mouth gape was measured from the beginning itself. Mouth gape measured was $0.10 \mathrm{~mm}$ at the time of opening. The yolk sac got fully absorbed by $3 \mathrm{dph}$. Gut content on 5th day indicated undigested nauplii of size $83.78-93.3 \mu \mathrm{m}$ in length and $35.42-45.39 \mu \mathrm{m}$ in width. The gut contents of 8 dph larvae consisted of both late naupliar stages and copepodites. Late naupliar stages measured around $116.12 \mu \mathrm{m}$ and copepodites measures between 291.26 and $112.11 \mu \mathrm{m}$ in length and width varied in between $31.13 \mu \mathrm{m}$ and $89.62 \mu \mathrm{m}$. The gut contents of 11th and 14th days were mainly composed of late copepodite stages which were measured in between 420.25 and $530.42 \mu \mathrm{m}$ in length and $130.23-156.24 \mu \mathrm{m}$ in width. At 17th day, remnants of adult copepods were present in the gut contents. The total length measured as $605.96-630.5 \mu \mathrm{m}$ and width measured as $158.36-165.12 \mu \mathrm{m}$. Mouth gape is the common measure of indicator for prey size of fish and fish larvae (Schmitt and Holbrook, 1984: Bremigan and Stein, 1994; De Vries et al., 1998; Gill, 2003; Scharf et al., 2000). It is very clear that the larvae preferred bigger sized copepods at later stages of development. Though, there were sufficient numbers of naupliar stages in the tank, the larvae preferred large sized copepods towards later stages of their development. Burgess and Callan (2018) indicated that the yellow tang (Zebrasoma flavescens) larvae preferred large sized copepods in the later stages of the larval life from 6 dph onwards. However, Jackson and Lenz (2016) indicated the escape reflex of adult Parvocalanus

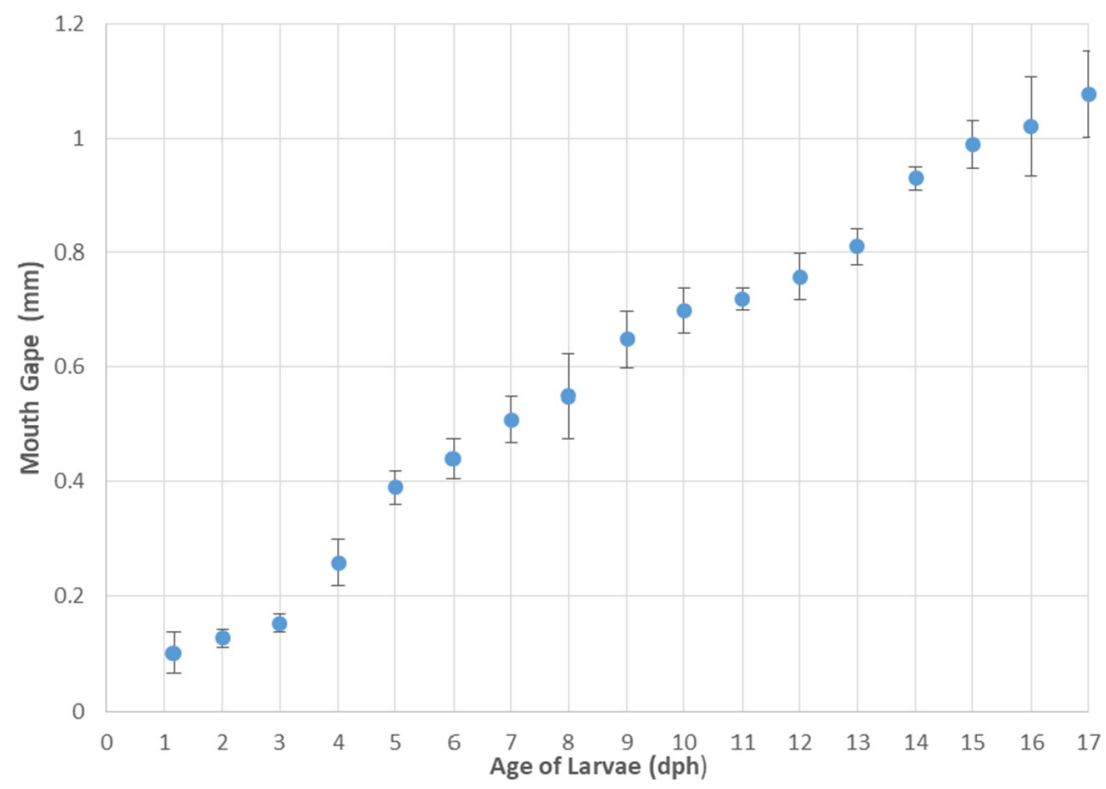

Fig. 8. Daily increment in mouth gape of $D$. carneus $(n=10)$ during initial larval rearing. 
Table 1

Physico-chemical parameters during larval rearing.

\begin{tabular}{ll}
\hline Physico-chemical parameters & Value (mean $\pm \mathrm{SD}$ ) \\
\hline Salinity (ppt) & $35.43 \pm 0.53$ \\
Water temperature $\left({ }^{\circ} \mathrm{C}\right)$ & $28.35 \pm 1.15$ \\
Dissolved oxygen $\left(\mathrm{mg} \mathrm{L}^{-1}\right)$ & $7.5 \pm 0.5$ \\
Total ammoniacal nitrogen (TAN) $\left(\mathrm{mg} \mathrm{L}^{-1}\right)$ & $0.37 \pm 0.05$ \\
$\mathrm{NH}_{3}-\mathrm{N}\left(\mathrm{mg} \mathrm{L}^{-1}\right)$ & $0.024 \pm 0.007$ \\
$\mathrm{NH}_{4}-\mathrm{N}\left(\mathrm{mg} \mathrm{L}^{-1}\right)$ & $34 \pm 0.04$ \\
$\mathrm{pH}$ & $7.88 \pm 0.38$ \\
\hline
\end{tabular}

crassirostris is more in comparison to larval strike of Amphiprion ocellaris. In addition to mouth gape of larvae, sensory detection and escape reflex of copepod influenced the capture success of larvae at later stages. When the feed was surplus, the larvae preferred bigger sized copepods as feed proportional to their development.

\subsubsection{Larval rearing protocol}

During the larval rearing, water temperature measured was $28.35 \pm 1.15^{\circ} \mathrm{C}$, salinity was maintained at $35.43 \pm 0.53 \mathrm{ppt}$. $\mathrm{pH}$ range was $7.88 \pm 0.38$. Dissolved oxygen varied between 6 and $8 \mathrm{mg} \mathrm{L}^{-1}$. Total ammoniacal nitrogen (TAN) measured was $0.37 \pm 0.05 \mathrm{mg} \mathrm{L}^{-1}$, NH3-N measured was $0.024 \pm 0.007 \mathrm{mg} \mathrm{L}^{-1}$ and $\mathrm{NH}_{4}-\mathrm{N}$ was in the range of $0.34 \pm 0.04 \mathrm{mg} \mathrm{L}^{-1}$ (Table 1).

When the larval mouth opened by 28 th hour $(1.16 \mathrm{dph})$ with commencement of first feeding, the naupliar stages were filtered out using $60 \mu \mathrm{m}$ and $35 \mu \mathrm{m}$ sieve combination. The naupliar stages retained in $35 \mu \mathrm{m}$ sieve were fed to the larvae up to $8 \mathrm{dph}$. Copepod density was counted daily and compensated with copepods of required stage from mass culture tanks. The copepodite stages were obtained by serial filtration through a combination of sieves of $100 \mu \mathrm{m}$ and $60 \mu \mathrm{m}$ till 10 dph. Similarly, adult copepods were separated using sieve of $170 \mu \mathrm{m}$ and fed to larvae till $25 \mathrm{dph}$ so that all the larvae surpass the planktonic stage $(22-23)$ with least mortality. Once and after the settlement of all the larvae, Artemia was used as feed and this continued till all the larvae metamorphosed into juveniles ( $50 \mathrm{dph}$ ). Artificial diet of $500 \mu \mathrm{m}$ size was used from $33 \mathrm{dph}$ and fishes were completely weaned to artificial feed from $50 \mathrm{dph}$.

Average survival rate obtained in the optimization of feeding trial was $2.56 \%$, which is the first record on successful larval rearing of $D$. carneus. For D. albisella and D. aruanus, Danilowicz and Brown (1992) observed survival of $0.1-41.2 \%$ using co-culture of algae, rotifer and plankton. Gopakumar and Santhosi (2009) got 3-8\% survival at 25th day for $D$. aruanus and 3-4\% survival for $D$. trimaculatus using mixed copepod as feed. Gopakumar et al. (2009a), obtained survival rates ranging between 10 and $15 \%$ using copepods and rotifers in $D$. aruanus and $D$. trimaculatus. In the present study, only copepods were used till $25 \mathrm{dph}$ and later supplemented with Artemia nauplii enriched with microalgae till completion of metamorphosis (50 dph). In the light of studies conducted on mouth gape assessment and prey preference,

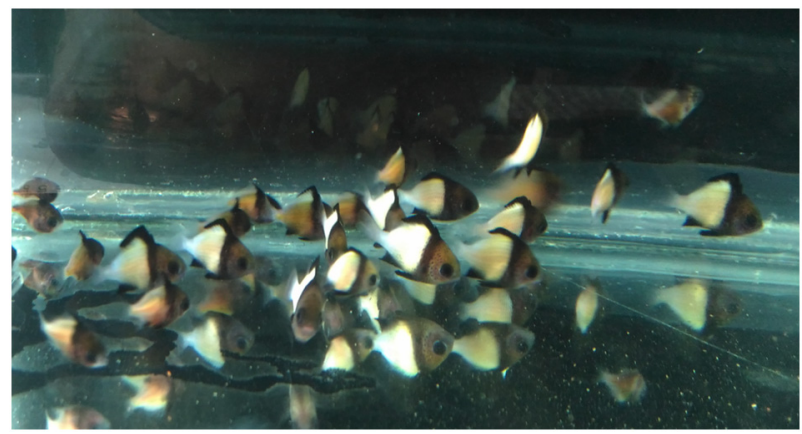

Fig. 10. Juveniles of $D$. carneus $75 \mathrm{dph}$.

specific feeding practice with required size of copepods need to be adopted for getting better survival in the larval rearing of $D$. carneus.

Better survival rates (3.4 to $8.7 \%$ ) were obtained from successive larval rearing conducted by feeding serial combination of stages of copepods from nauplii to adult as indicated in Fig. 9. Artificial feed was used from $33 \mathrm{dph}$ onwards. Critical period of initial larval survival in $D$. carneus were 3 to $7 \mathrm{dph}$. Systematic feeding regime was followed in relation to mouth gape suggested a gradual shift of preference in feeding copepods from nauplii at $2 \mathrm{dph}$ to adult at $15 \mathrm{dph}$. Overlapping regimes were followed in case of copepods and Artemia from $25 \mathrm{dph}$ onwards and Artemia and artificial feeds from $33 \mathrm{dph}$ and the larvae were completely weaned to artificial diet from $50 \mathrm{dph}$. The larval rearing protocol has been finalized and summarized in (Fig. 9). Adequate supply of copepods of required size identified by the present experiment holds the key for improving production of cloudy damsel larvae. Both 75 days (Fig. 10) and 150 days (Fig. 11) old juveniles fully resembles adult in colouration and behaviour.

\subsection{Size at first maturity}

The fishes matured and showed courtship behaviour at 160-182 days in captivity and subsequently started spawning within 10-15 days. The SL and weight of fishes which spawned for the first time was $33 \mathrm{~mm}$ and $3 \mathrm{~g}$ for male and $28 \mathrm{~mm}$ and $2.8 \mathrm{~g}$ for female respectively. In the wild, individuals with maturing ovary ranged from 17.7 to $49.2 \mathrm{~mm}$ in SL, with mature ovary from 24 to $52 \mathrm{~mm}$ and with functional testis ranged from 31.4 to $56.6 \mathrm{~mm}$ (Asoh and Yoshikawa, 2003). D. carneus was observed to mature and breed at a much smaller size than all its congeners which fully agrees with the observations of Randall and Allen (1977).

\section{Conclusion}

Development of larval rearing protocols of marine ornamental fishes shall definitely reduce their exploitation from natural ecosystem especially for trade. The popular ornamental fishes of the Genus Dascyllus,

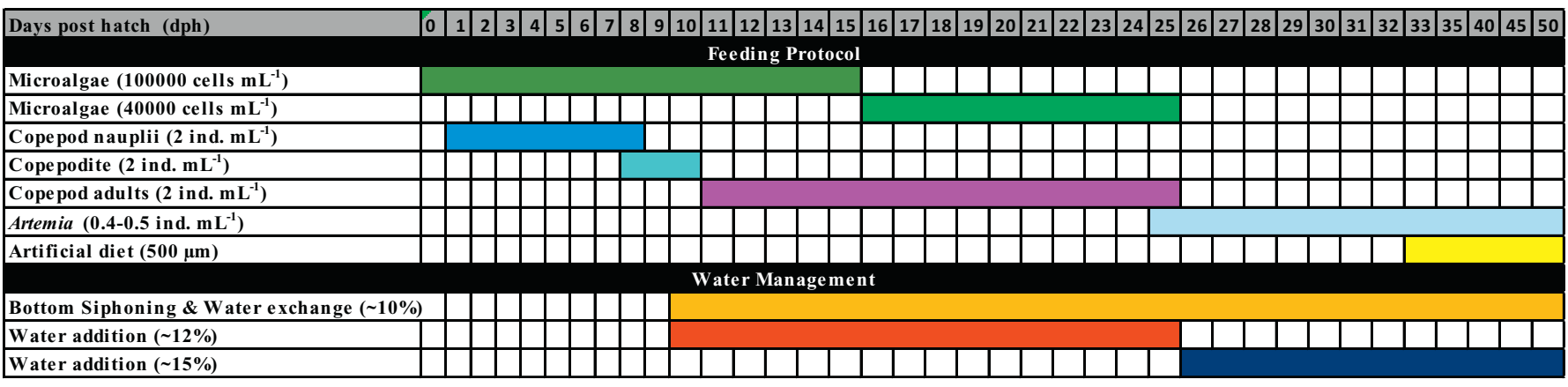

Fig. 9. Standardised feeding and water management protocol developed for larval rearing of D. carneus. 


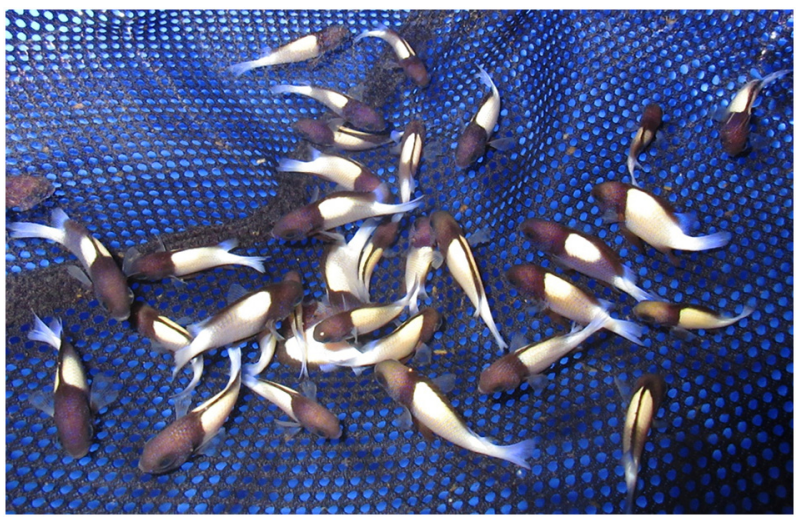

Fig. 11. Juveniles of D. carneus $150 \mathrm{dph}$.

has been found to be one of the most difficult group for seed production due to its smaller eggs and altricial type of larvae. This is the first-ever successful work on broodstock development, breeding, description of developmental stages and larval rearing of cloudy damsel Dascyllus carneus under captivity. The present study proved the efficiency of calanoid copepod Parvocalanus crassirostris in successful captive rearing of D. carneus. Larval gut content in relation to mouth gape helped in determining feed size preferences of larval stages and the larval rearing protocols were finalized accordingly.

\section{Acknowledgements}

We extend our sincere thanks to Dr. Imelda Joseph, Head of Mariculture Division, ICAR-CMFRI and Dr. G. Gopakumar, Emeritus Scientist and Former Head, Mariculture Division, ICAR-CMFRI for the immense support and encouragement extended during the work. This work was carried under the Project 'Development of hatchery technologies for prioritized species in mariculture' (MDN/HCY/18) fully supported by ICAR-CMFRI and sincere gratitude to the Project Leader Dr. A.K. Abdul Nazar, Principal Scientist, Mandapam Regional Centre of ICAR-CMFRI, Mandapam, Tamil Nadu for his support and assistance. The authors also extend thanks to Dr. Ritesh Ranjan, Visakhapatnam Regional Centre of ICAR-CMFRI for his support and encouragements. We express our sincere gratitude to Mr. M. Arif, for his support in statistical analysis. The authors are thankful to all the staff of Vizhinjam Research Centre of CMFRI for their cooperation and support.

\section{References}

Allen, G.R., 1991. Damselfishes of the World. Mergus Publishers, Melle, Germany. Alshuth, S.R., Tucker, J.W., Hateley, J., 1998. Egg and larval development of laboratoryreared sergeant major, Abudefduf saxatilis (Pisces, Pomacentridae). Bull. Mar. Sci. 62, $121-133$.

Anzeer, F.M., Santhosh, B., Aneesh, K.S., Abraham, Mijo V., Unnikrishnan, C., 2018. Biological information and culture techniques of Parvocalanus crassirostris (F. Dahl, 1894) var. cochinensis. In: Santhosh, B., Anil, M.K., Anzeer, F.M., Aneesh, K.S., Abraham, Mijo V., Gopakumar, G., Rani Mary, G., Gopalakrishnan, A., Unnikrishnan, C. (Eds.), Culture Techniques of Marine Copepods. ICAR-Central Marine Fisheries Research Institute, Kochi, Kerala, India, pp. 59-66.

APHA, 1998. Standard Methods for the Examination of Water and Wastewater, twentieth ed. American Public Health Association, New York.

Arai, T., 2015. Diversity and conservation of coral reef fishes in the Malaysian South China Sea. Rev. Fish Biol. Fish. 25, 85-101.

Asoh, K., Yoshikawa, T., 2003. Gonadal development and non-functional protogyny in the Indian damsel fish. Dascyllus carneus. J. Zool. (Lond.). 260, 23-39.

Battaglene, S.C., Cobcroft, J.M., 2007. Advances in the culture of striped trumpeter larvae: a review. Aquaculture. 268, 195-208.

Bell, J.G., Tocher, D.R., Henderson, R.J., Dick, J.R., Crampton, V.O., 2003. Altered fatty acid compositions in Atlantic salmon (Salmo salar) fed diets containing linseed and rapeseed oils can be partially restored by a subsequent fish oil finishing diet. J. Nutr. 133, 2793-2801.

Biondo, M.V., 2017. Quantifying the trade in marine ornamental fishes into Switzerland and an estimation of imports from the European Union. Glob. Ecol. Conserv. 11, 95-105.

Bremigan, M.T., Stein, R.A., 1994. Gape-dependent larval foraging and zooplankton size: implications for fish recruitment across systems. Can. J. Fish. Aquat. Sci. 51 (4), 913-922.

Brough, C., McBirney, C., Brough, D., 2018. Cloudy Damsel. Animal world-pet and animal information. http://animalworld.com/encyclo/marine/damsels/striped.php, Accessed date: 7 October 2018.

Burgess, A.I., Callan, C.K., 2018. Effects of supplemental wild zooplankton on prey preference, mouth gape, osteological development and survival in first feeding cultured larval yellow tang (Zebrasoma flavescens). Aquaculture 495, 738-748. https://doi. org/10.1016/j.aquaculture. 2018.06.046.

Carassou, L., Le Borgne, R., Ponton, D., 2009. Diet of pre-settlement larvae of coral-reef fishes: selection of prey types and sizes. J. Fish Biol. 75 (3), 707-715. https://doi.org/ 10.1111/j.1095-8649.2009.02312.x.

Chlupaty, P., 1957. Dascyllus aruanus, der Preussenfisch. Aquar. Terrar. 122-124.

Chong, V.C., Lee, P., Lau, C.M., 2010. Diversity, extinction risk and conservation of Malaysian fishes. J. Fish Biol. 76, 2009-2066. https://doi.org/10.1111/j.1095-8649. 2010.02685.x.

Coates, D., 1982. Some observations on the sexuality of humbug damselfish, Dascyllus aruanus (Pisces, Pomacentridae) in the field. Z. Tierpsychol. 59, 7-18. https://doi. org/10.1111/j.1439-0310.1982.tb00328.x.

Cobb, R.V., 1975. Spawning cloudy damsels. Mar. Aquarist. 6 (7), 46-49.

Cole, K.S., 2002. Gonad morphology, sexual development, and colony composition in the obligate coral-dwelling damselfish Dascyllus aruanus. Mar. Biol. 140, 151-163. https://doi.org/10.1007/s002270100681.

Cooper, W.J., Santini, F., 2016. A revised damselfish taxonomy with a description of the tribe Microspathodontini (giant damselfishes). In: Parmentier, E., Frédérich, B. (Eds.), The Biology of Damselfishes. CRC Press, Boca Raton, FL, pp. 13-30.

Copeman, L.A., Parrish, C.C., Brown, J.A., Harel, M., 2002. Effects of docosahexanoic, eicosapentaenoic and arachidonic acids on the early growth, survival, lipid composition and pigmentation of yellowtail flounder (Limanda ferruginea): a live food enrichment experiment. Aquaculture 210, 285-304.

Danilowicz, B.S., Brown, C.L., 1992. Rearing methods for two damsel fish species Dascyllus albisella (Gill) and D. aruanus (L.). Aquaculture 106, 141-149.

De Vries, D.R., Stein, R.A., Bremigan, M.T., 1998. Prey selection by larval fishes as influenced by available zooplankton and gape limitation. Trans. Am. Fish. Soc. 127, 1040-1050.

Fishelson, L., 1964. Observations on the biology and behaviour of Red Sea coral fishes. Bull. Sea Fish. Res. Sta. Haifa. 37, 11-26.

Fotedar, R.K., Phillips, B.F., 2011. Recent Advances and New Species in Aquaculture. Wiley-Blackwell, pp. 461.

Fricke, H.W., Holzberg, S., 1974. Social units and hermaphroditism in a pomacentrid fish. Naturwiss. 61, 367-368.

Fricke, R., Mulochau, T., Durville, P., Chabanet, P., Tessier, E., Letourneur, Y., 2009. Annotated checklist of the fish species (Pisces) of La Réunion, including a red list of threatened and declining species. Stuttgarter Beiträge zur Naturkunde A Neue Serie. 2, 1-168.

Fricke, R., Eschmeyer, W.N., van der Laan, R. (Eds.) 2018. Catalog of fishes: genera, species, references. http://researcharchive.calacademy.org/research/ichthyology/ catalog/fishcatmain.asp. Electronic version (accessed 28 December 2018).

Froese, R., Pauly, D., 2018. FishBase. http://www.fishbase.org/, Accessed date: 26 June 2018.

Getlekha, N., Molina, W., Cioffi, M., Yano, C., Maneechot, N., Bertollo, C.A.L., Supiwong, W., Tanomtong, A., 2016. Repetitive DNAs highlight the role of chromosomal fusions in the karyotype evolution of Dascyllus species (Pomacentridae, Perciformes). Genetica 144. https://doi.org/10.1007/s10709-016-9890-5.

Gill, A.B., 2003. The dynamics of prey choice in fish: the importance of prey size and satiation. J. Fish Biol. 63, 105-116.

Gopakumar, G., Santhosi, I., 2009. Use of copepods as live feed for larviculture of damselfishes. Asian Fish. Sci. 22 (1), 1-6.

Gopakumar, G., Sreeraj, G., Ajithkumar, T.T., Sukumaran, N.T., Raju, B., Unnikrishnan, C., Hillary, P., Benziger, V.P., 2002. Breeding and larval rearing of three species of damselfishes (family: Pomacentridae). Mar. fish. Inform. Ser. T\&E Ser 171, 3-5.

Gopakumar, G., Ignatius, B., Santhosi, I., Ramamoorthy, N., 2009a. Controlled breeding and larval rearing techniques of marine ornamental fishes. Asian Fish. Sci. 22, 797-804.

Gopakumar, G., Madhu, K., Madhu, R., Ignatius, B., Krishnan, L., Mathew, G., 2009b. Broodstock development, breeding and seed production of selected marine food fishes and ornamental fishes. Mar. Fish. Inform. Ser. T\&E Ser 201, 1-9.

Hattori, A., Casadeva, M., 2016. Sex change strategies and group structure of damsel fishes. In: Frédérich, B., Parmentier, E. (Eds.), Biology of Damselfishes. Taylor \& Francis, CRC Press, pp. 55-83.

Jackson, J.M., Lenz, P.H., 2016. Predator-prey interactions in the plankton: larval fish feeding on evasive copepods. Sci. Rep. 6, 33585. Published 2016 Sep 23. https://doi. org/10.1038/srep33585.

Kavanagh, K.D., Alford, R., 2003. Sensory and skeletal development and growth in re lation to the duration of the embryonic and larval stages in damselfishes (Pomacentridae). Biol. J. Linn. Soc. 80, 187-206.

Kovac, V., Copp, G.H., 1999. Prelude: looking at early development in fishes. Environ. Biol. Fish 56, 7-14.

Llopiz, J.K., Cowen, R.K., 2009. Variability in the trophic role of coral reef fish larvae in the oceanic plankton. Mar. Ecol. Prog. Ser. 381, 259-272. https://doi.org/10.3354/ meps07957.

Madhu, K., Rema, M., 2014. Captive spawning and embryonic development of marine ornamental purple firefish Nemateleotris decora (Randall \& Allen, 1973). Aquaculture 424 (42), 1-9.

Madhu, K., Rema, M., Gopakumar, G., 2013. Present status of marine ornamental fish breeding and technology developed under captivity. J. Basic Appl. Biol. 7 (3), 
$164-170$

Moorhead, J.A., Zeng, C., 2010. Development of captive breeding techniques for marine ornamental fish: a review. Rev. Fish. Sci. 18 (4), 315-343.

Munk, P., 1997. Prey size spectra and prey availability of larval and small juvenile cod. J. Fish Biol. 51, 340-351. https://doi.org/10.1111/j.1095-8649.1997.tb06107.x.

Murphy, B.F., Leis, J.M., Kavanagh, K.D., 2007. Larval development of the Ambon damselfish Pomacentrus amboinensis, with a summary of pomacentrid development. J. Fish Biol. 71, 569-584.

Olivotto, I., Cardinali, M., Barbaresi, L., Maradonna, F., Carnevali, O., 2003. Coral reef fish breeding: the secrets of each species. Aquaculture 224, 69-78.

Olivotto, I., Holt, S.A., Carnevali, O., Holt, J.G., 2006a. Spawning, early development and first feeding in the lemonpeel angelfish Centropyge flavissimus. Aquaculture 253, $270-278$.

Olivotto, I., Rollo, A., Sulpizio, R., Avella, M., Tosti, L., Carnevali, O., 2006b. Breeding and rearing the sunrise Dottyback Pseudochromis flavivertex: the importance of live prey enrichment during larval development. Aquaculture 255, 480-487.

Olivotto, I., Capriotti, F., Buttino, I., Avella, A.M., Vitiello, V., Maradonna, F., Carnevali, O., 2008. The use of harpacticoid copepods as live prey for Amphiprion clarkii larviculture: effects on larval survival and growth. Aquaculture 274, 347-352. https:// doi.org/10.1016/j.aquaculture.2007.11.027.

Ostergaard, P., Munk, P., Janekarn, V., 2005. Contrasting feeding patterns among species of fish larvae from the tropical Andaman Sea. Mar. Biol. 146, 595-606. https://doi. org/10.1007/s00227-004-1458-8.

Planas, M., Cunha, I., 1999. Larviculture of marine fish: problems and perspectives. Aquaculture 177, 171-190. https://doi.org/10.1016/S0044-8486(99)00079-4.

Prakash, S., Kumar, T.T.A., Raghavan, R., Rhyne, A., Tlusty, M.H., Subramoniam, T., 2017. Marine aquarium trade in India: challenges and opportunities for conservation and policy. Mar. Policy 77, 120-129.

Randall, H.A., Allen, G.R., 1977. A revision of the damselfish genus Dascyllus (Pomacentridae) with the description of a new species. Rec. Aust. Mus. 31 (9), 349-385.

Rohini Krishna, M.V., Anil, M.K., Neethu Raj, P., Santhosh, B., 2016. Seed production and growth of Neopomacentrus cyanomos (Bleeker, 1856) in captivity. Indian J. Fish 63, 50-56. https://doi.org/10.21077/ijf.2016.63.3.55058-06.

Sale, P.F., 1970. Behaviour of the humbug fish. Aust. Nat. Hist. 16, 362-366.

Sampey, A., Mckinnon, A.D., Meekan, M.G., Mccormick, M.I., 2007. Glimpse into guts: a first overview of the feeding of tropical shore fish larvae. Mar. Ecol. Prog. Ser. 339, 243-257.

Santhosh, B., Anil, M.K., Anzeer, F.M., Aneesh, K.S., Abraham, M.V., Gopakumar, G., Rani, Mary G., Gopalakrishnan, A., Unnikrishnan, C. (Eds.), 2018. Culture Techniques of Marine Copepods. ICAR-Central Marine Fisheries Research Institute, Kochi, Kerala, India.

Sargent, J.R., McEvoy, L.A., Bell, J.G., 1997. Requirements, presentation and sources of polyunsaturated fatty acids in marine fish larval feeds. Aquaculture 155 (1-4), 117-127. https://doi.org/10.1016/S0044-8486 (97)00122-1.

Satoh, N., Takeuchi, T., 2009. Estimation of the period sensitive for the development of abnormal morphology in brown sole Pseudopleuronectes herzensteini fed live food enriched with docosahexaenoic acid. Fish. Sci. 75, 985-991. https://doi.org/10. 1007/s12562-009-0121-1.

Satoh, S., Poe, W.E., Wilson, R.P., 1989. Studies on the essential fatty acid requirement of channel catfish, Ictalurus punctatus. Aquaculture 79, 121-128. https://doi.org/10. 1016/0044-8486(89)90452-3.

Scharf, F.S., Juanes, F., Rountree, R.A., 2000. Predator size-prey size relationships of marine fish predators: interspecific variation and effects of ontogeny and body size on trophic-niche breadth. Mar. Ecol. Prog. Ser. 208, 229-248.

Schmitt, R.J., Holbrook, S.J., 1984. Gape-limitation, foraging tactics and prey size selectivity of two micro carnivorous species of fish. Oecologia 63, 6. https://doi.org/10. 1007/BF00379778.

Schwarz, A., Smith, L.C., 1990. Sex change in the damselfish Dascyllus Reticulatus (Richardson) (Perciformes: Pomacentridae). Bull. Mar. Sci. 46 (3), 790-798.

Setu, S.K., Ajith Kumar, T.T., Balasubramanian, T., Dabbagh, A.R., Keshavarz, M., 2010. Breeding and rearing of regal damselfish Neopomacentrus cyanomos (Bleeker, 1856): the role of green water in larval survival. World J. Fish. Mar. Sci. 2 (6), 551-557.

Shirota, A., 1970. Studies on the mouth size of fish larvae. Bull. Jpn. Soc. Sci. Fish. 36, 353-367.

Sin, T.M., Teo, M.M., Peter Ng, K.L., Chou, L.M., Khoo, H.W., 1994. The damselfishes (Pisces: Osteichthyes: Pomacentridae) of peninsular Malaysia and Singapore: systematics, ecology and conservation. Hydrobiologia 285, 49-58. https://doi.org/10. 1007/BF00005653.

Somarakis, S., Nikolioudakis, N., 2010. What makes a late anchovy larva? The development of the caudal fin seen as a milestone in fish ontogeny. J. Plankton Res. 32 (3), $317-326$.

Sreeraj, G., 2002. Studies on the Reproductive Biology, Breeding and Larval Rearing of Selected Marine-Ornamental Fishes Belonging to the Family Pomacentridae ( $\mathrm{Ph}$. D Thesis). PGPM, ICAR-Central Institute of Fisheries Education, Central Marine Fisheries Research Institute, Mumbai, pp. 185. http://eprints.cmfri.org.in/id/eprint/ 7130.

Stevenson, R.A., 1963. Life history and behaviour of Dascyllus albisella Gill, a pomacentrid reef fish (Ph.D. dissertation). Univ. Hawaii 221

Stottrup, J.G., Norsker, N.H., 1997. Production and use of copepods in marine fish larviculture. Aquaculture 155, 231-248.

Sun, B., Fleeger, J.W., 1995. Sustained mass culture of Amphiascoides atopus a marine Harpacticoid copepod in a recirculating system. Aquaculture 136, 313-321. https:// doi.org/10.1016/0044-8486(95)01064-5.

Suzuki, K., Hioki, S., Kurita, M., 1985. Life history of the damselfish Chromis notatus in Suruga bay. Japan. J. Fac. Mar. Sci. Tech. Tokai Univ. 21, 115-127.

Sweet, T., 2016. The state of marine Breeders' art, 2017. CORAL 13 (6) Available. http:// www.reef2rainforest.com/2016/11/17/coral-magazines-captive-bred-marine-fishspecies-list-for-2017/.

Tanaka, Y., 1999. Reproductive behaviour, eggs and larvae of four Dascyllus species in the aquarium. J. Fac. Mar. Sci. Tech. Tokai Univ. 47, 223-244.

Vagelli, A.A., 2004. Significant increase in survival of captive-bred juvenile banggai cardinalfish Pterapogon kauderni with an essential fatty acid-enriched diet. J. World Aquacult. Soc. 35, 61-69.

Wickler, V.W., 1967. Vergleich des Albaichverhaltens einiger paarbildender sowie nichtpaarbildender Pomacentriden und Cichliden (pisces: Perciformes). Z. Tierpsychol. 24, 457-470.

Yúfera, M., Darias, M.J., 2007. The onset of feeding in marine fish larvae. Aquaculture 268, 53-63. 